\title{
EN TORNO A UNOS MANUSCRITOS DE JOVELLANOS REFERENTES AL DIALECTO ASTURIANO
}

Según su propio testimonio, Jovellanos conocía y aún hablaba desde su niñez el idioma de la región asturiana, este dialecto al que denominamos bable. Dado su interés por todo lo relacionado con esta región española, en la que había nacido, nada tiene de extraño se fijase en su particular idioma, esforzándose por desentrañar sus valores y por lo que de él se podía sacar, para el mejor conocimiento de nuestra historia y costumbres.

Aparte las referencias en sus cartas y otros escritos a nuestro dialecto, hay dos trabajos más particulares, publicados en la Biblioteca de Autores Españoles, t. 46, p. 343-9 y t. 50, p. 205-211; el primero titulado: Apuntamiento sobre el dialecto de Asturias y el otro, una carta a Posada, seguida de una Instrucción para un diccionario de la lengua asturiana.

A mi poder han llegado, hace tiempo, dos escritos de Jovellanos, que se refieren al mismo tema. El primero es una carta «sobre el Dialecto de Asturias» y el segundo titulado «Instrucción para la formación del dialecto asturiano». Ninguno de los dos coincide con los escritos publicados en la BA'E. Ambos son totalmente de puño y letra del mismo Jovellanos y con numerosas correciones.

El primer trabajo lo conoció probablemente D. Julio Somoza, a juzgar por una anotación suya que aparece en un papel que estaba junto con los manuscritos y aunque la carta no va dirigida a nadie en particular, de la nota de Somoza parece deducirse que iba en principio dirigida a D. Francisco de Paula Caveda, entre cuyos papeles se encontraba. Son nueve páginas, tamaño cuartilla, de letra menuda; carece de fecha, si bien la letra coincide bastante con unas autógrafas de Jovellanos de 1799 y 1800 , y dirigidas al mismo D. Francisco. Las cinco primeras páginas y la mitad 
de la sexta están escritas a dos columnas; son dos redacciones distintas, ambas con múltiples correcciones. Las restantes lo están a una sola columna. Hemos hecho la transcripción de la que nos parecía más completa.

En esta carta nos dice cómo él conocía el dialecto asturiano ya desde su niñez; el estudio de las humanidades le llevó a interesarse por sus orígenes; pero no dispuso de comodidad y de tuempo para profundizar en estos es. tudios. Para subir a los origenes del dialecto, dice, no es necesario remontarse hasta los primeros pobladores. EI dialecto asturiano es hijo legítimo de la sola lengua latina. Según él los romanos no conquistaron el interior de Asturias; que por otra parte debía de estar muy poco poblado; que su población posterior debe atribuirse a los mismos romanos, que con sus sa" bias leyes y equitativo gobierno, su lengua y sus costumbres cultas, los pocos o muchos transmontanos, no debieron de ofrecerles resistencia y esto no tanto por vía de conquista, como de convencimiento.

El segundo escrito, al contrario del publicado en la BAE sobre el mismo tema, no está en forma de carta y solmmente de instrucción; parece incompleto y en el habla tanto del Diccionario del dialecto asturiano, como del histórico y geográfico, con él relacionado. No obstante el título de la portada, que ya no es de letra de Jovellanos, lo denomina «Instrucción para la formación del Diecionario del dialecto asturianon.

Como este trabajo está incompleto, no nos ha parecido transcribirlo, sin antes hacer de él un más detenido estudio.

\section{José María Patac de las Traviesas}

Gijón, 13 de Noviembre de 1978.

Amigo y Señor: Cuando emprendí mi viaje a este país creía yo que el dialecto que habla su pueblo, sería uno de los primeros objetos de mis observaciones. Habíale oído hablar de continuo y aunque le entendia y hablaba yo perfectamente en mi niñez pero ni entonces podía moverme a observar su índole, ni era capaz de subir a sus orígenos. El estudio de las humanidades me hizo advertir después, qué necesario era para el conocimiento de la lengua el examen analitico de su sintaxis y más partieularmente la indagación de los origenes de sus palabras y esta convicción junto a tal cual progreso adquirido por virtud de ella en mis observaciones a nombre de la lengua latina, me condujeron naturalmente a meditar sobre el origen de mi dialecto natural. Entonces conoci que conservándose solamente en la tradición. y el uso y careciendo enteramente de monumentos no solo impresos mas 
antés escritos, era imposible adelantar cosa alguna, no viniendó acá a suplir con la voz viva la falta de tan necesarios auxilios. Y vea Vm. aquí por qué cuando emprendi mi viaje, venía yo con tantos afanes prometiéndome que a mi vuelta podría por lo menos escribir una gramática, una ortografía y un glosario o etimológico del dialecto de Asturias.

Todas mis esperanzas volaron apenas me vi en el teatro de mis observaciones, entregado por orden superior a objetos de otra especie y de más alta importancia, llevado por ellos continuamente de un pueblo a otro y forzado, por decirlo así, a residir casi siempre en pueblos alejados y por temporadas breves e interrumpidas, tardé muy poco en conocer que no podía tener, ni las proporciones necesarias para hacer las observaciones que me había propuesto.

En efecto para hacerlas con fruto era necesario huir de las poblaciones agregadas, donde la residencia de la nobleza, alto clero y gente de letras, la concurrencia de forasteros y el uso más frecuente de la lengua castellana, han corrompido el dialecto popular, desterrando de él muchas voces, admitiendo muchas puramente castellanas y alterando su pronunciación y aún su sintaxis. Era también preciso buscar los concejos más interiores y de menos trato y comunicación con los pueblos agregados, residir en ellos despacio, oír, preguntar, escribir, comparar y en fin hacer un estudio detenido y reflexivo de mi objeto.

Renuncio, pues, a mis vastos proyectos y a mis alegres esperanzas acerca de este punto, pero no renuncio, ni por pienso, a decir a Vm. lo que he podido adelantar al mismo paso y como de corrida, a fuerza de preguntar y moler a cuantos se me pusieron a tiro. Este cuidado que no abandonaré jamás, en medio de mis ocupaciones me proporciona aliento a lo menos para ordenar algunas conjeturas acerca del origen de el dialecto asturia. no, las cuales comunicaré a Vm. en nuestra puridad, mientras puedo con estudio más reflexivo disponerme a las empresas que dejo indicadas.

Mas no espere Vm. amigo mío, que yo le entretenga con los sueños y cavilaciones de los etimologistas. Las conjeturas que formare estarán bastante apoyadas para no parecerse a ellos; y donde no alcanzare mi observación confesaré ninguna sin vergüenza, evitando con el mayor cuidado dar a Vm. gato por liebre.

Para subir a los orígenes del dialecto de Asturias no me parece necesario remontarse hasta los primeros pobladores de este país. Sean los que fueren, ello es que del idioma que pudieron introducir ya no hay vestigio alguno. 
Tal cual voz, cuyo origen no habiamos podido atinar, les pertenecerá tal vez. Tal vez un profundo indagador sabio en la Historia y en las lenguas antiguas podrá rastrear por ellas quiénes fueron los pobladores de Asturias y en qué tiempo y con qué idioma vinieron aquí. Pero no siendo este mi objeto, debo decir a Vm. claramente, que no cuento con ellos.

Digo también, para entrar cuanto antes en la materia, que el dialecto asturiano es hijo legítimo de la sola lengua latina, no por que no tenga absolutamente voz que no derive de ella, sino porque la mayor parte de sus voces tienen ahí su raíz y porque su índole y carácter se conforma enteramente con los de esta lengua matriz.

Antes de entrar en mis conjeturas permítame Vm. que con la luz de la Historia fije el tiempo en que la lengua de los romanos pudo entrar en este país: esto es, la época del primer origen de este dialecto.

Yo hallo que los romanos no sujetaron la Asturias transmontana: esto es, la que está de puertos acá, y hoy lleva solamente su antiguo nombre. La victoria de los generales de Augusto, fue en el país de los Astures Augustanos, esto es, de los que estaban de montes allá, colocados entre la orilla del río Astura, que, indudablemente es el Esla y la falda meridional de nuestros montes. Es verdad que la historia dice que bajaron los Asturianos de los montes y que seguramente sin ellos no hubieran podido los de la tierra llana resistir tan ferozmente al Señor del mundo: pero esto sólo probará que los romanos vencieron a algunos o sean muchos Astures transmontanos, pero no que conquistaran y se enseñorearan de mi país. Los Astures vencidos se retiraron a Lancia: ganáronla los romanos y es fama en esta plaza acabó su conquista. Pero estando ya averiguado que Lancia estaba a la parte de León y a ... leguas de esta ciudad y probablemente en el mismo sitio que hoy se llama Sollanzo, esto mismo vendrá a probar que los romanos se contentaron con sujetar los Astures Augustanos y no más.

Y esta opinión me parece tanto más probable, cuanto la población de la parte transmontana de Asturias debía ser entonces muy escasa. El Convento jurídico de Asturias que comprendía una tenía ciertamente gran población, que dice Plinio que contenía doscientas y . mil perso. nas, todas libres: mas yo creo que la mayor parte de esta población vivía en el reino de León, ocupando todo el país que se extiende hasta las orillas del Esla, vasto y pingüe territorio, y muy capaz de comprender tantos habitantes.

Por otra parte los geógrafos no nos han dejado memoria de ningún pueblo interior de la Asturias Transmontana. En Strabón y Plinio se conservan 
los nombres de algunos pueblos situados sobre la costa, ponen ésos sin ninguna nota de exaltación y confederación, como acostumbraban hacer con los que la merecían y señaladamente hicieron con Astúrica, Gigia y Lancia, perteneciente a la Asturias Augustana. Es pues de creer que la otra parte de los montes estuviese poco poblada.

Ni en mi concepto los Astures, que bajaron de las alturas, eran transmontanos, sino probablemente Augustanos, lo primero porque la caída de los montes que miran al mediodía pertenecía a éstos, lo segundo porque, del contexto de Floro, se infiere que los que bajaron eran los mismos que se habían opuesto a los romanos y estos eran sin disputa los Augustanos, que se habían situado en las alturas para resistir con más ventaja al poder de las legiones.

No negaré yo que los romanos pudieron hacer por mar alguna expedición sobre los Astures transmontanos, pues también tomaron esta precaución digna de su sabia política, con los Cántabros, como dice Floro y la descripción que hace Plinio de esta orilla, junto al silencio de lo interior del país hace creer que ella sola era bastante conocida aún en tiempo de Trajano.

De todo inferiré, bien que solo como una conjetura: $10^{\circ}$ que los romanos no conquistaron lo interior de este país que hoy se llama Asturias, 2. $q u e$ este país debía estar por entonces muy poco poblado, $3 .^{\circ}$ que su prodigiosa población debe atribuirse a los mismos romanos.

En efecto, dueños éstos de todo el país llano de la parte meridional de los montes; introducidas sus sabias leyes y equitativo gobierno, su lengua, y sus costumbres cultas, los pocos o sean muchos transmontanos situados a la banda de acá, no debieron hacer resistencia en revueltas a ellos y esto, no por vía de conquista, sino por la de convención. A mi ver el texto de Floro probablemente: Desde entonces, dice, (esto es después de tomada Lancia.........

y estas expresiones, que comprenden no menos a los Astures que a los Cántabros convencen que un gran proclive estuvo al ánimo de estos valerosos pueblos, a reconocer la dominación de los romanos. 


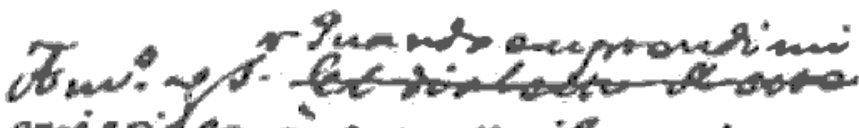

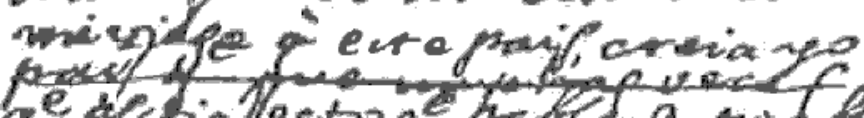

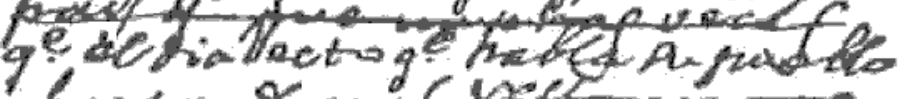

"amprantil:

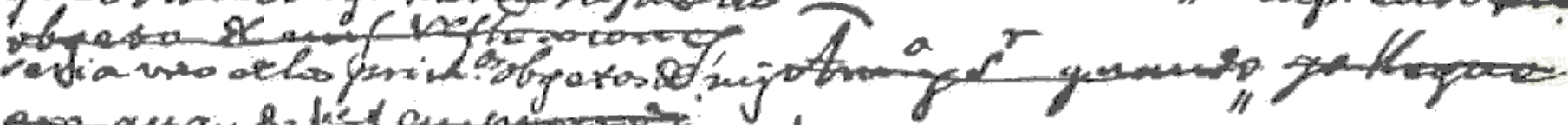

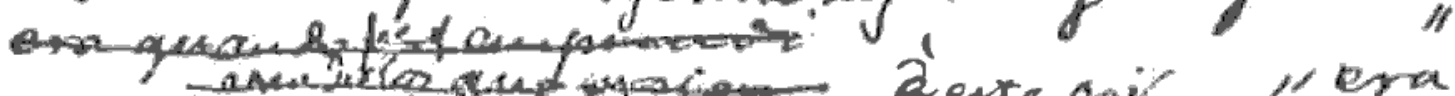

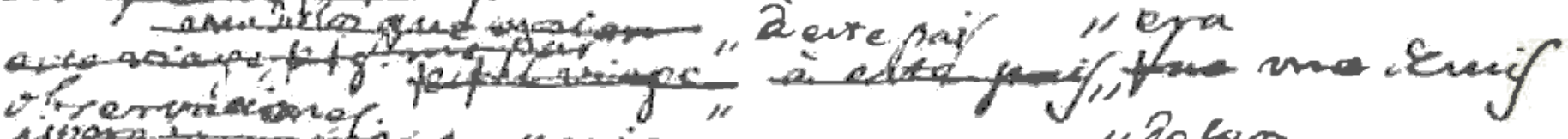

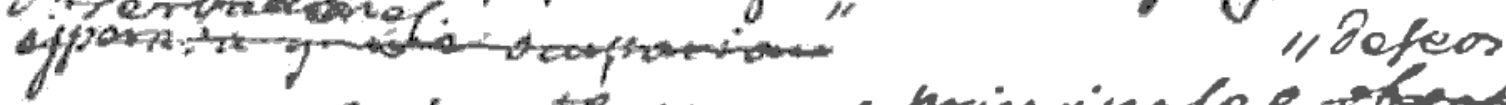

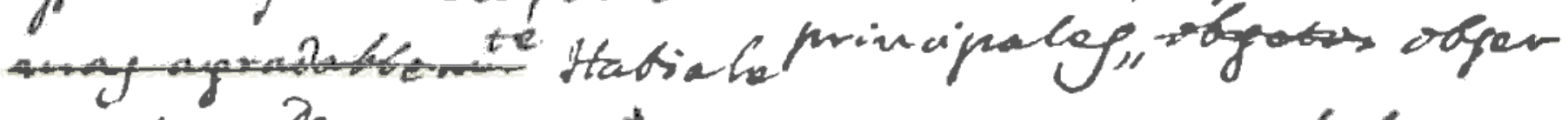

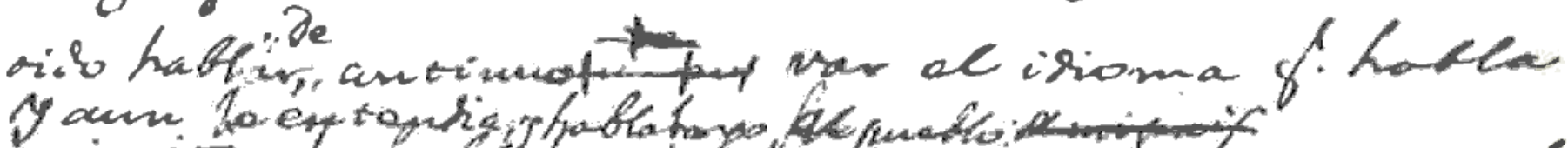

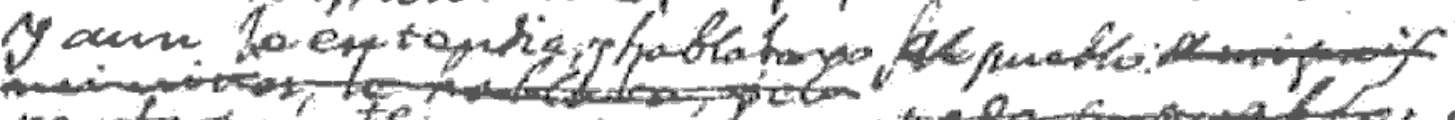

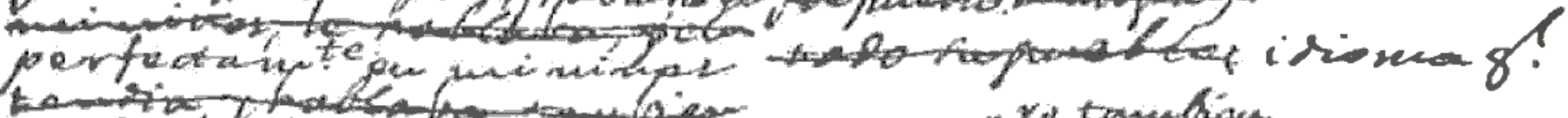

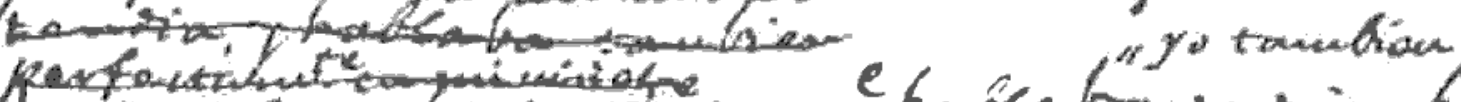

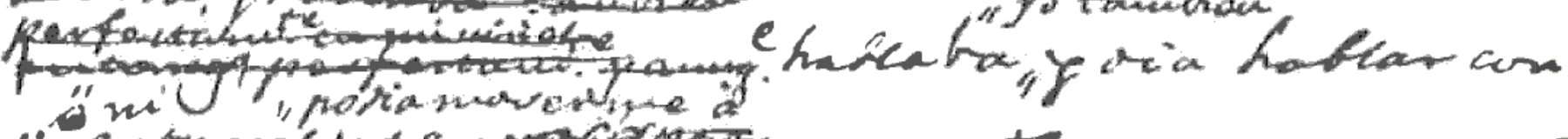

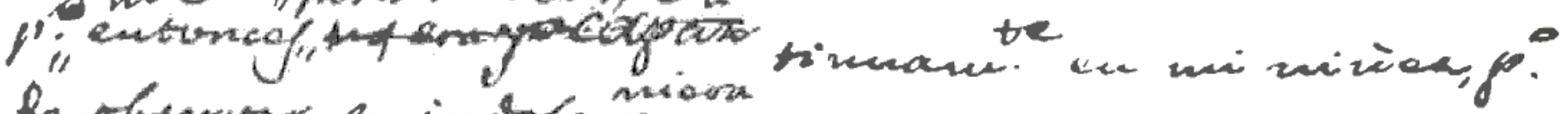

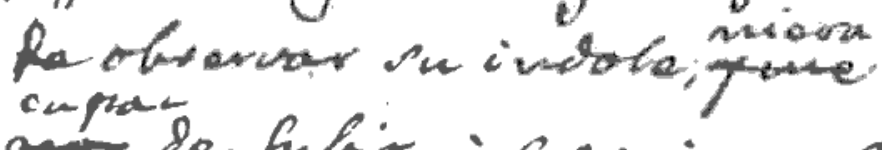

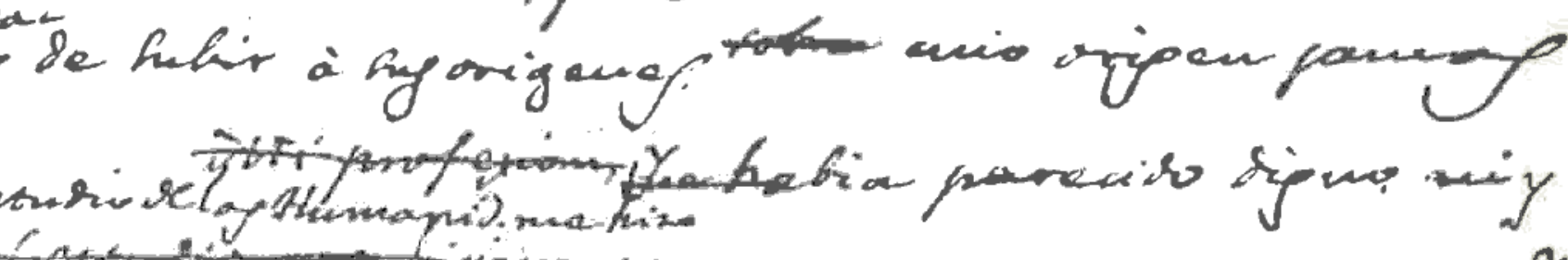

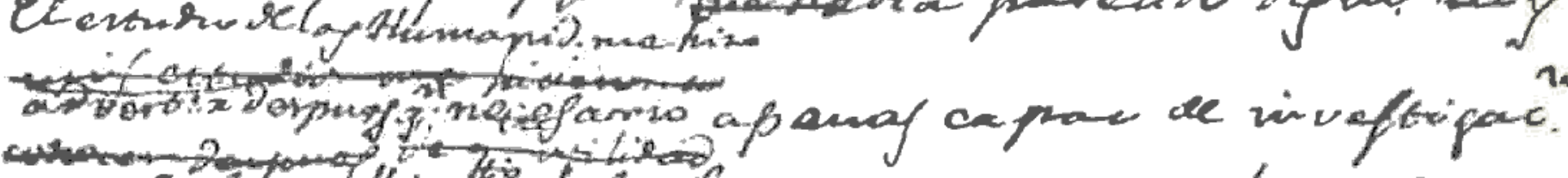

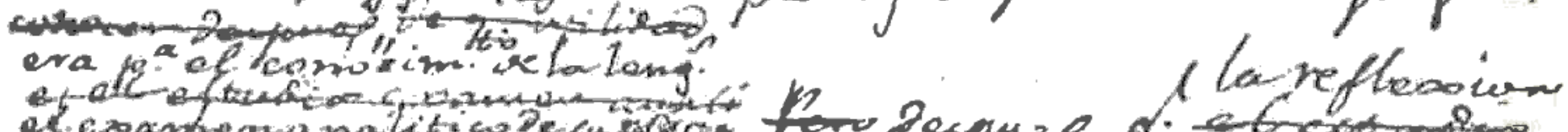

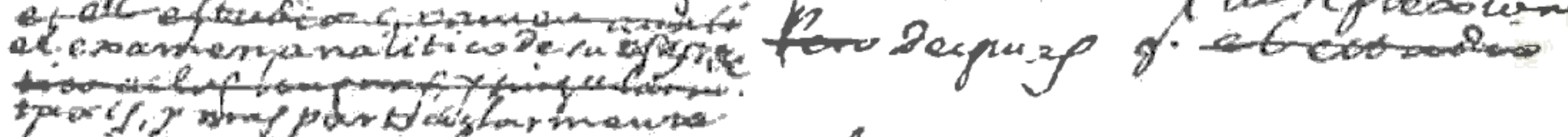

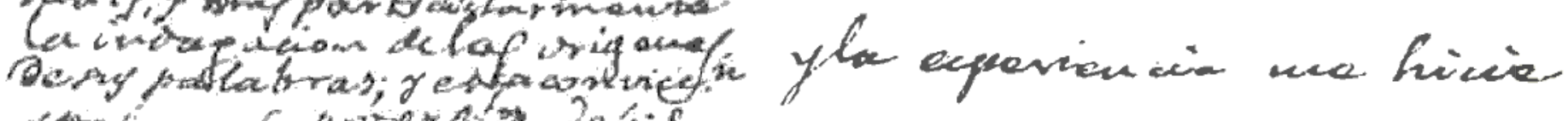

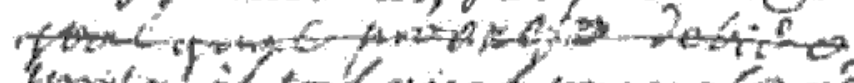

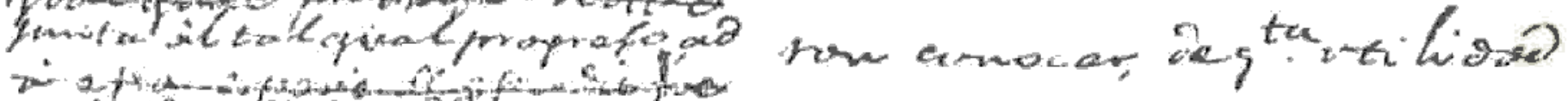

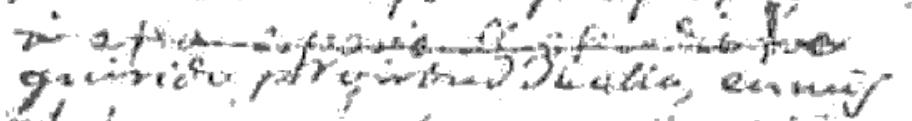

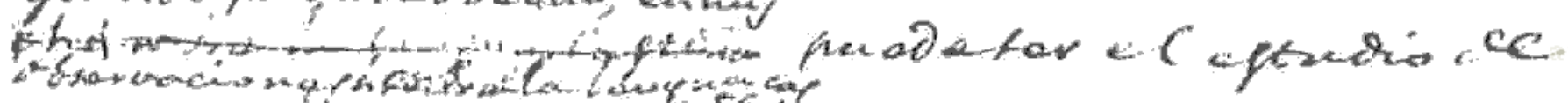

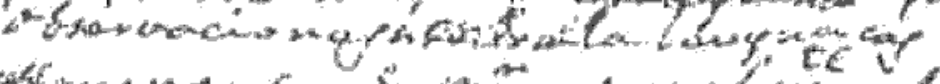

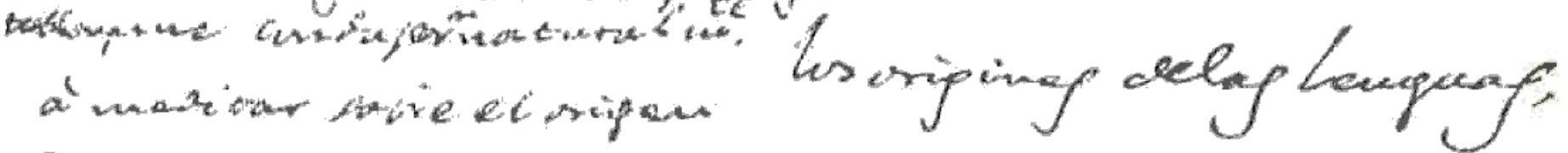

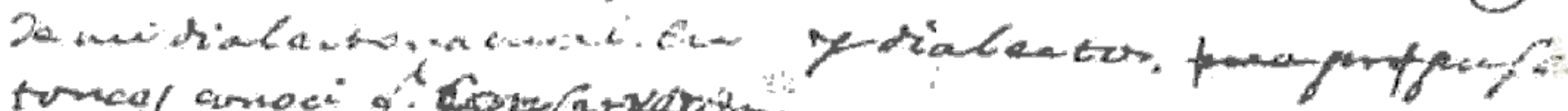

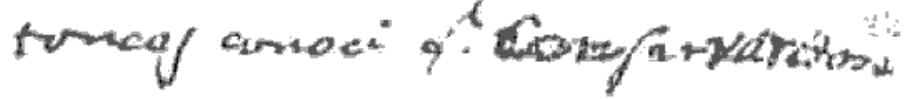




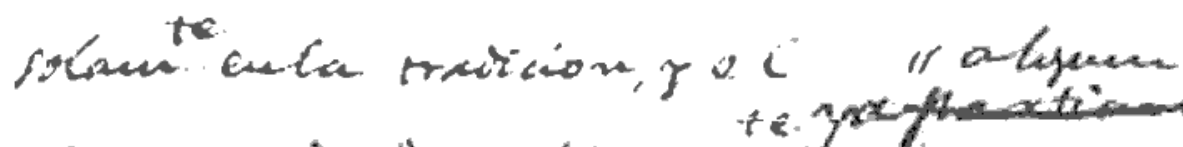

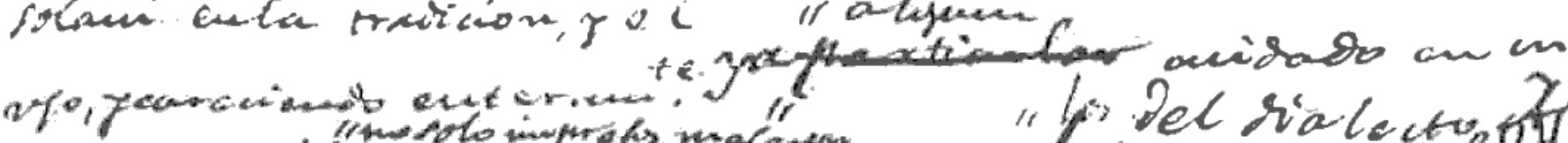

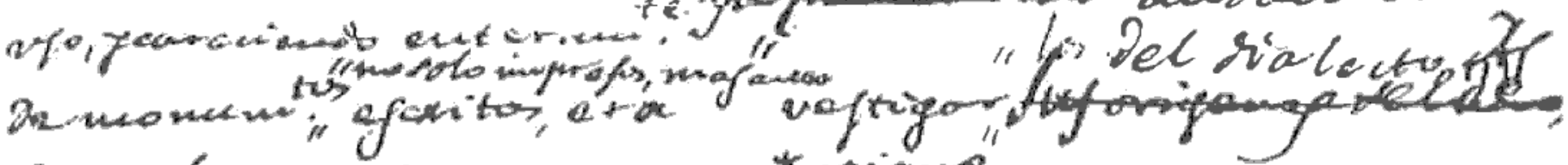

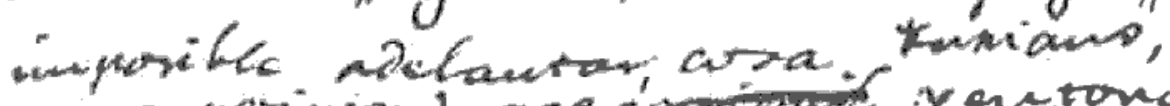

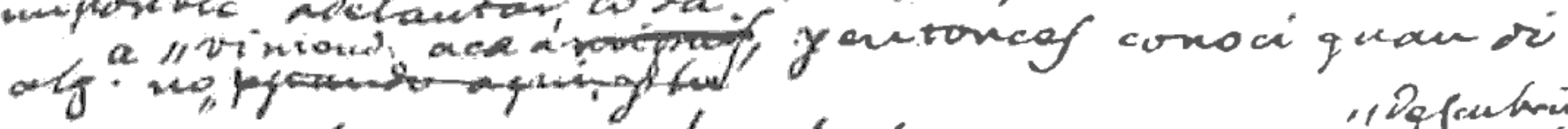

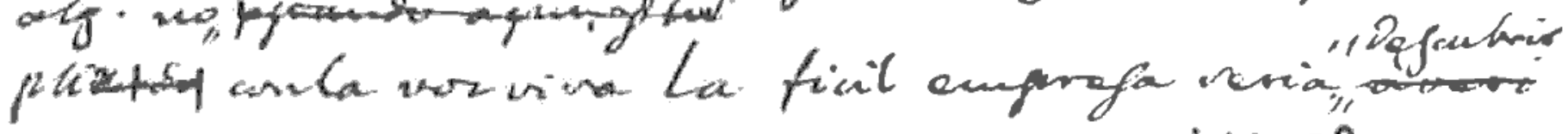

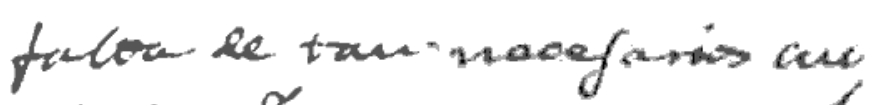

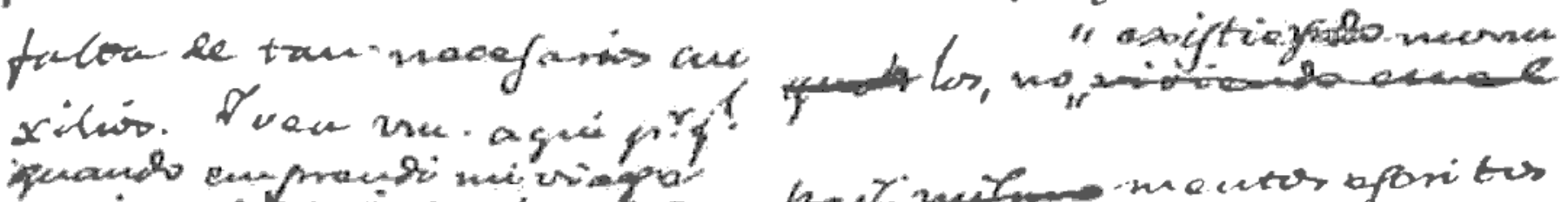

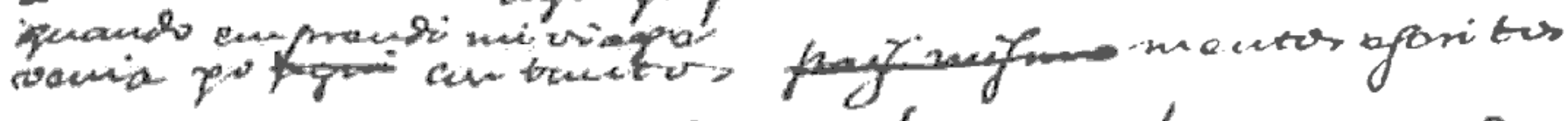

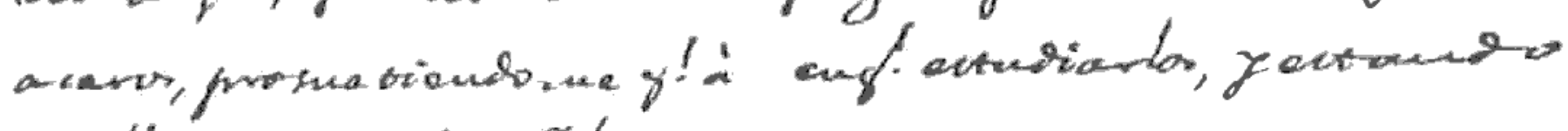
miftecter porria prome

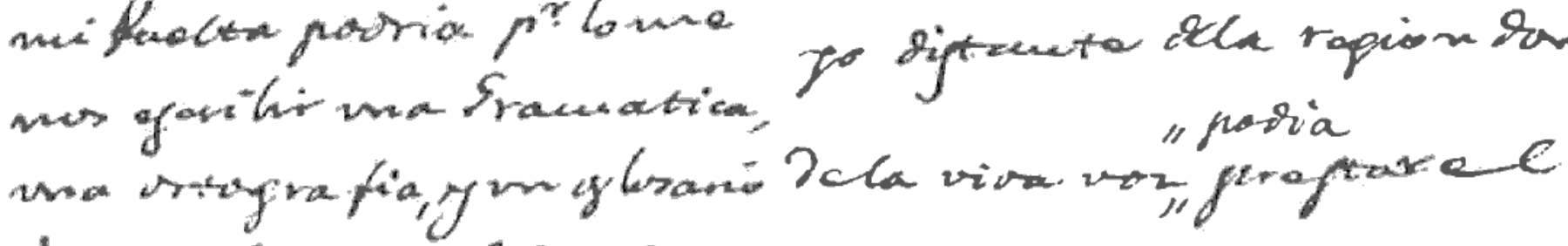

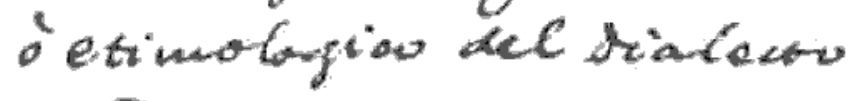
E. Afouniags

ige veptabive

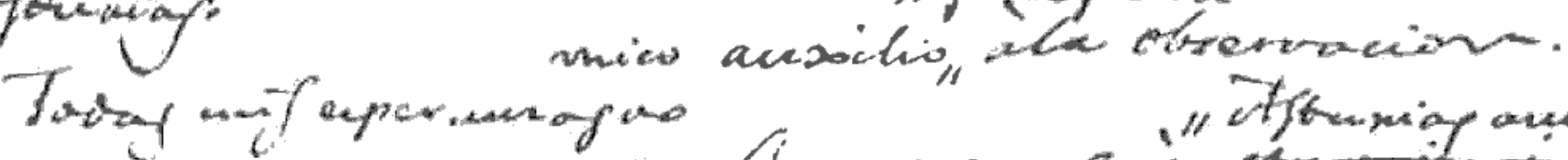

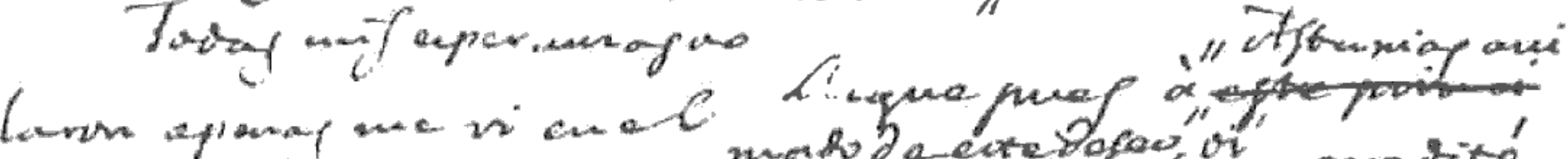

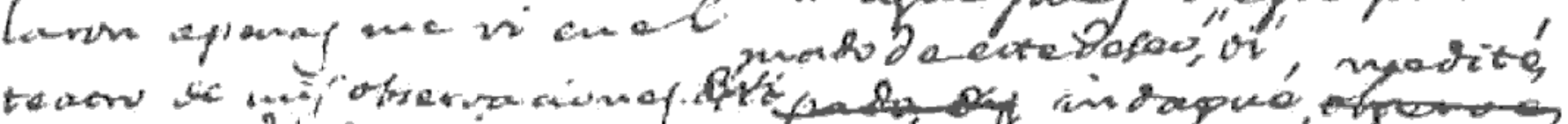

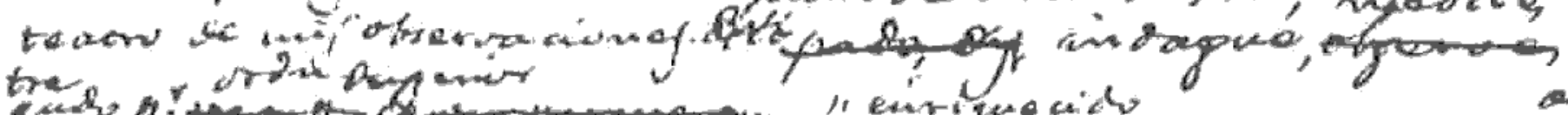

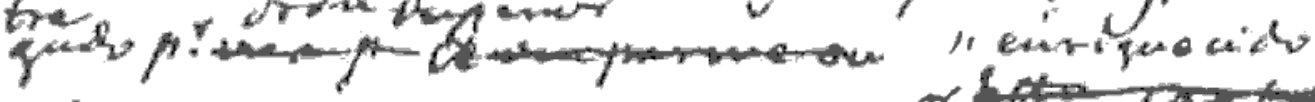

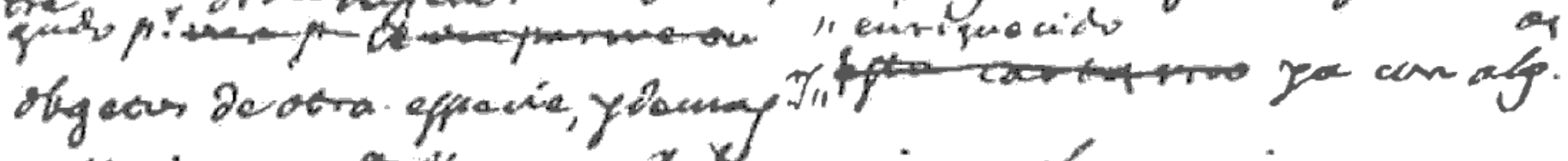

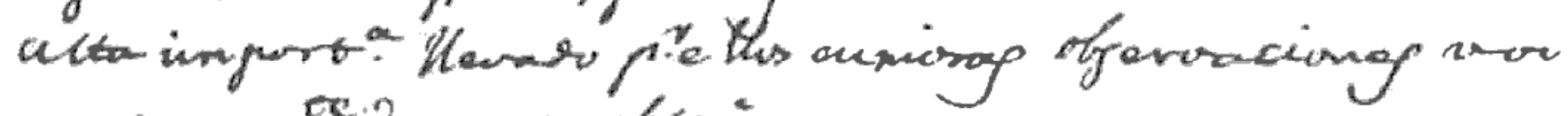

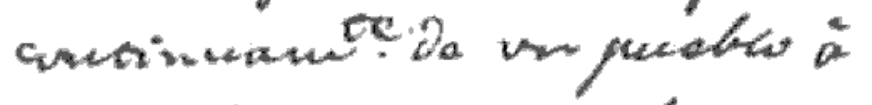

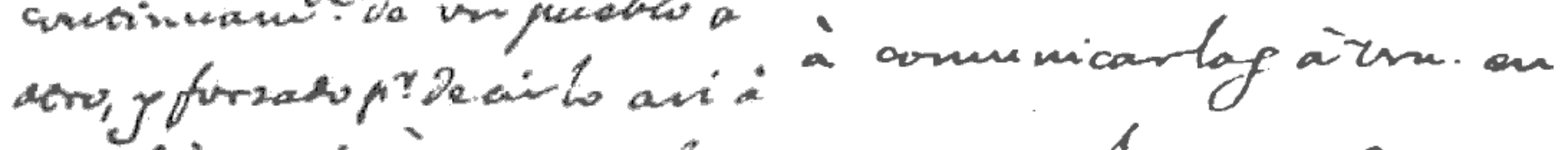

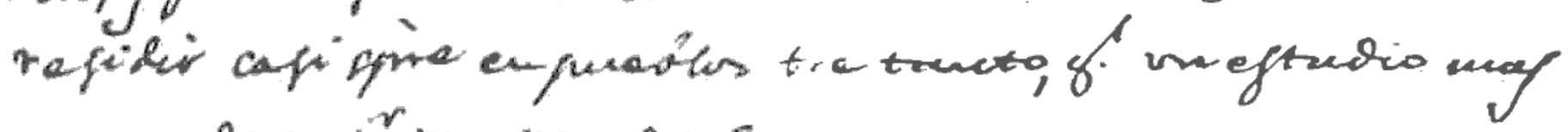

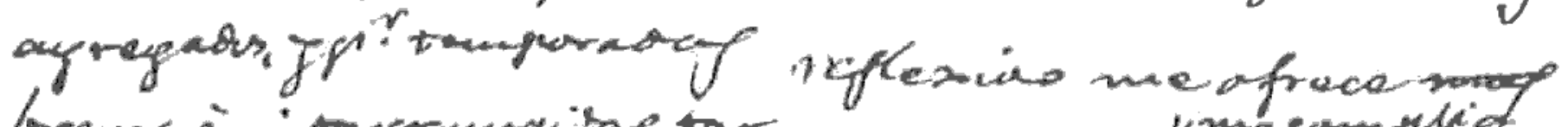

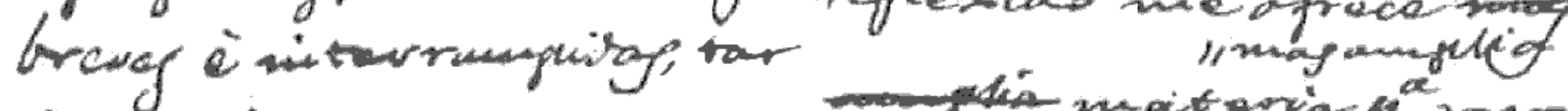

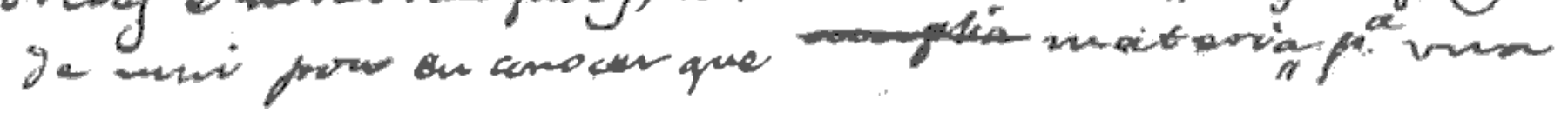




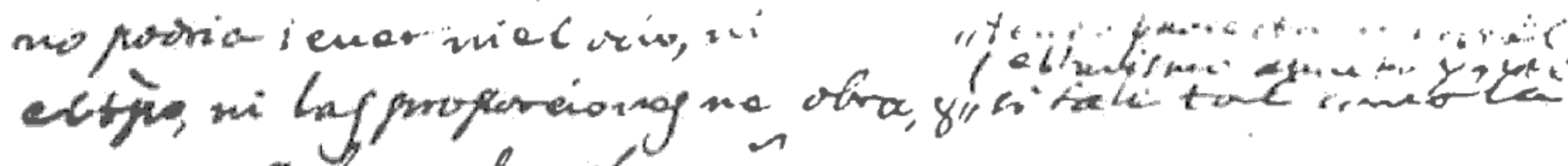

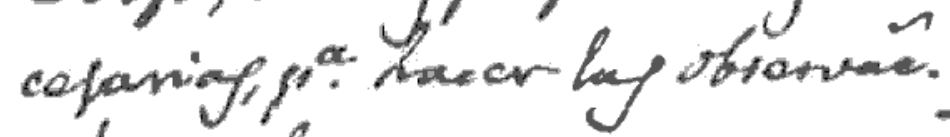
gima habia propreago.

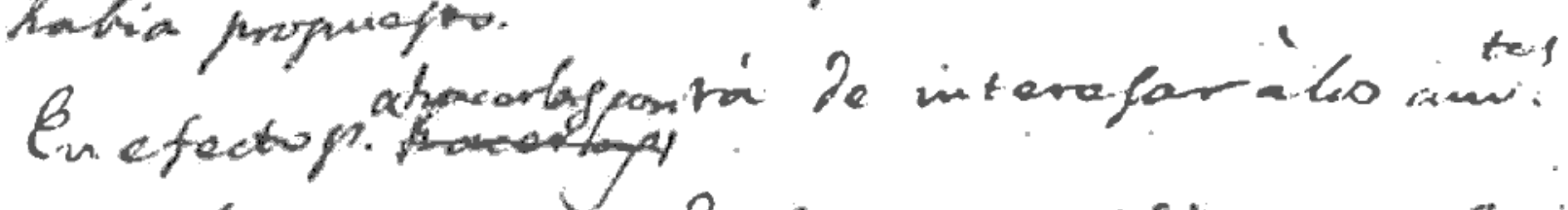

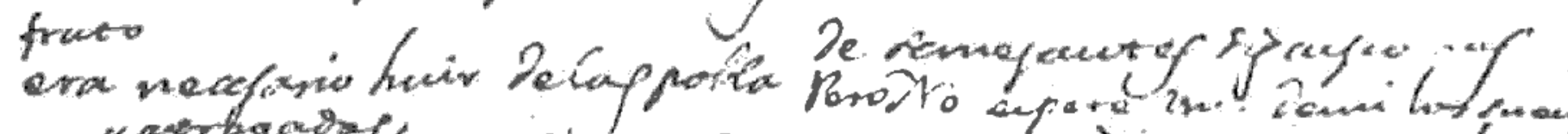
cioneforinde la regipdaciabe.

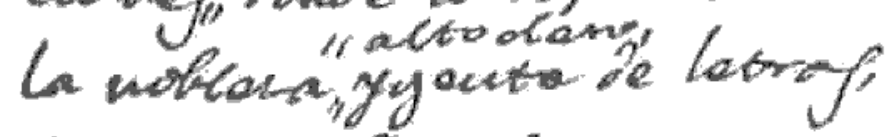

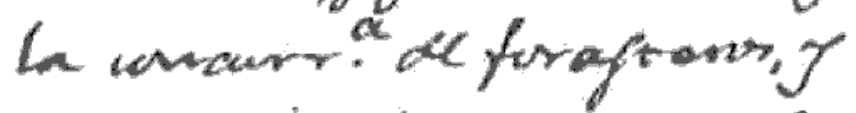
el yo ming fracuoute de la Lengua caforateono han co

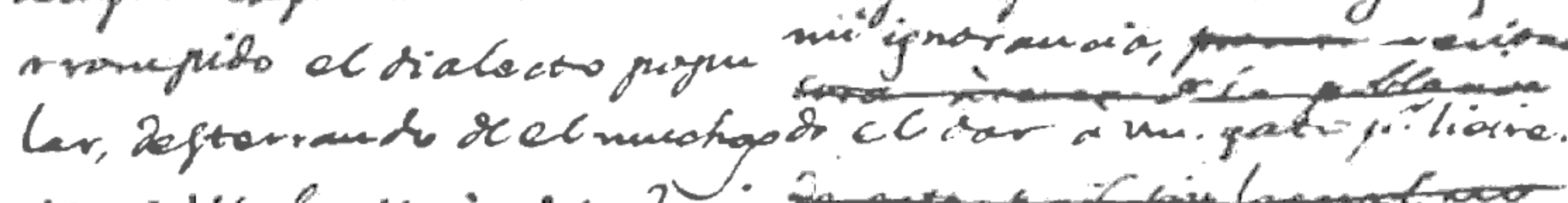

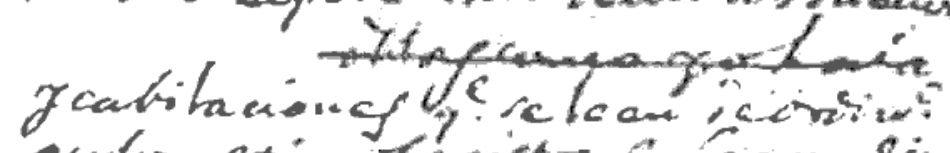

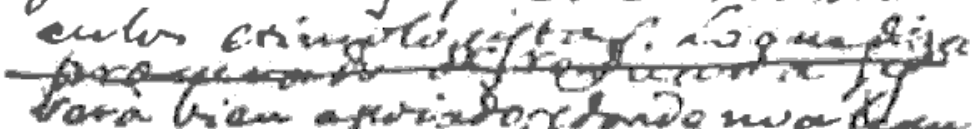

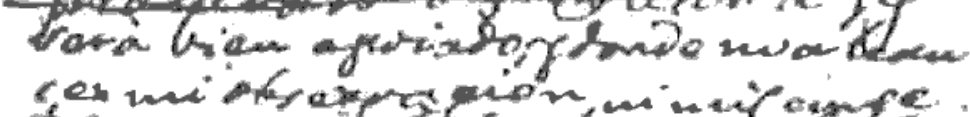

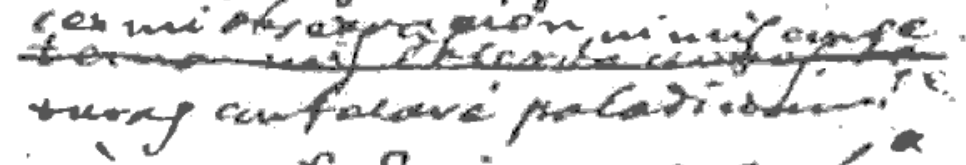

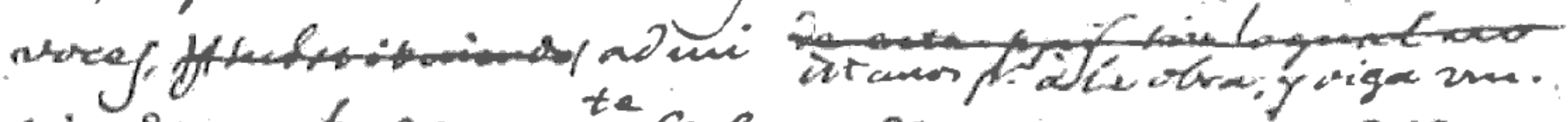

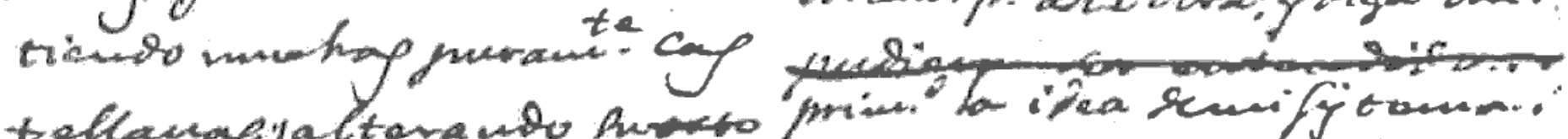

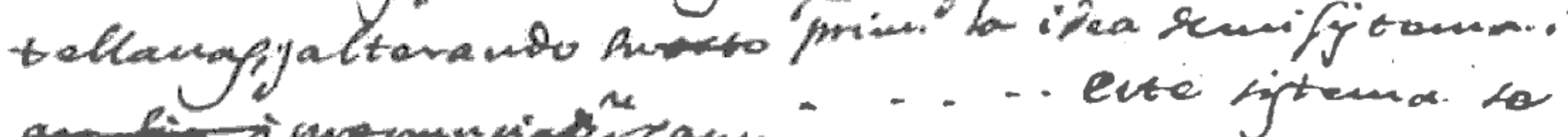

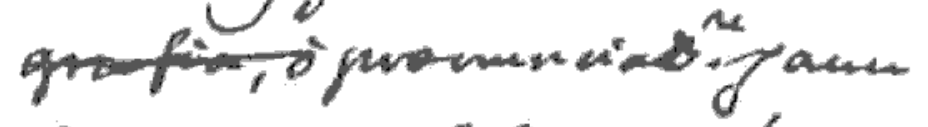

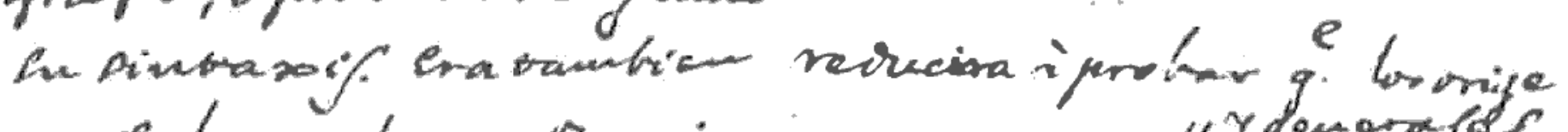

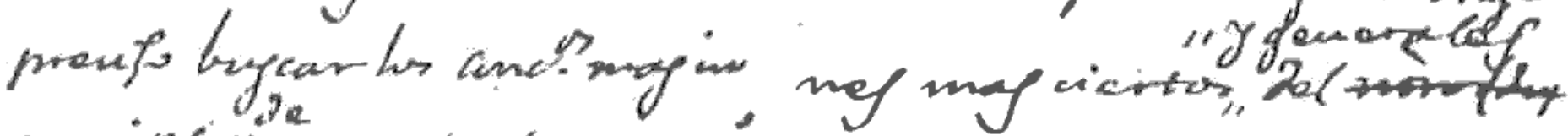

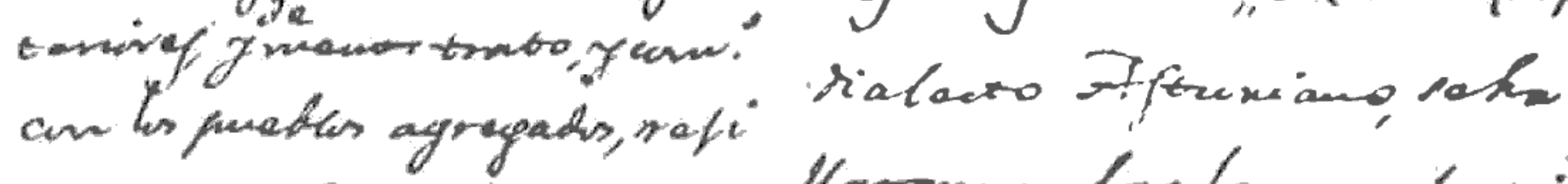

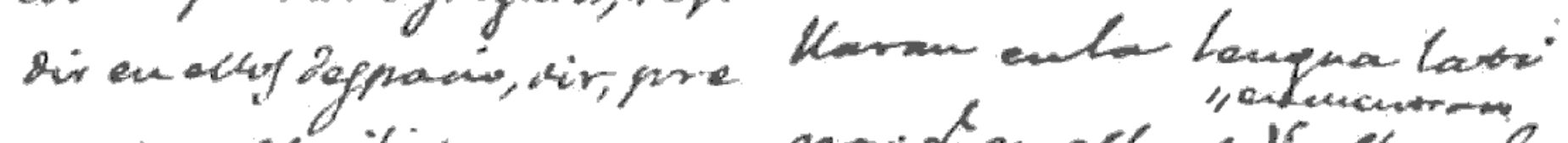

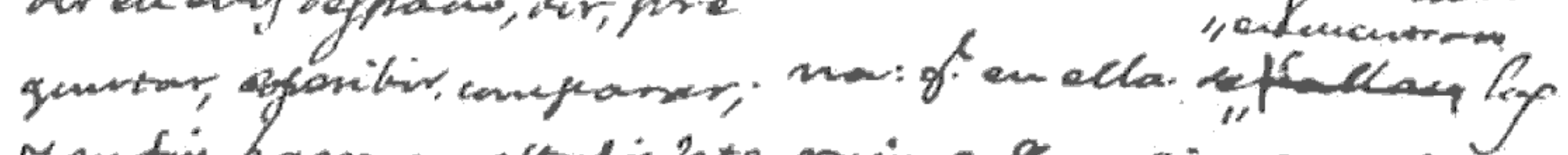

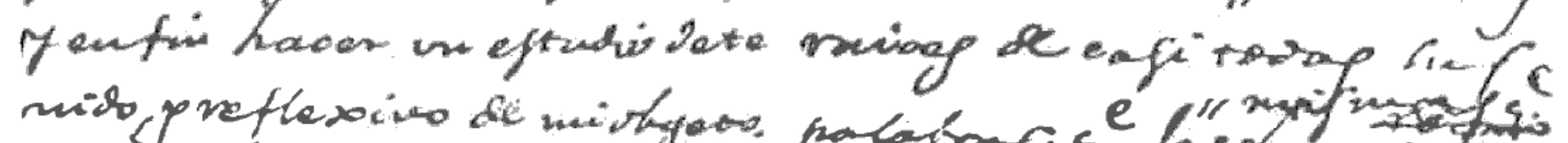

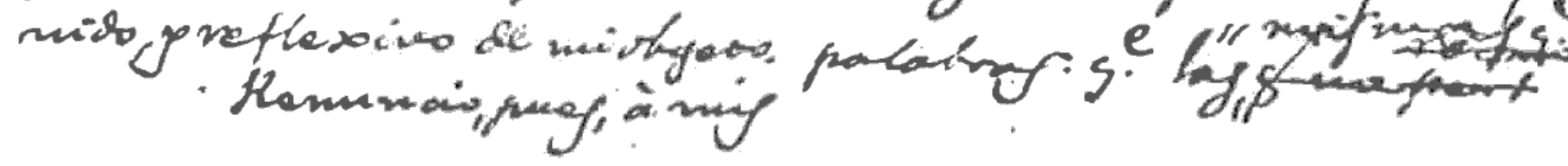




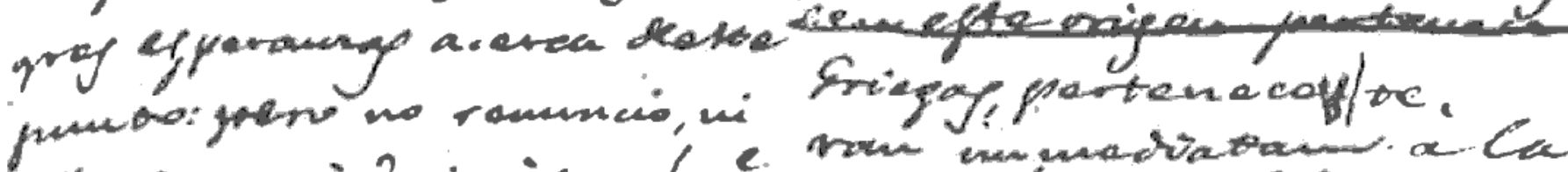

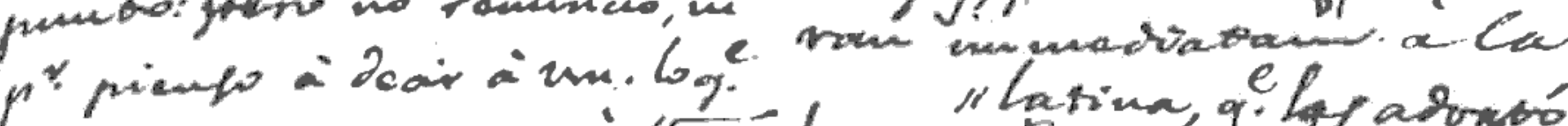

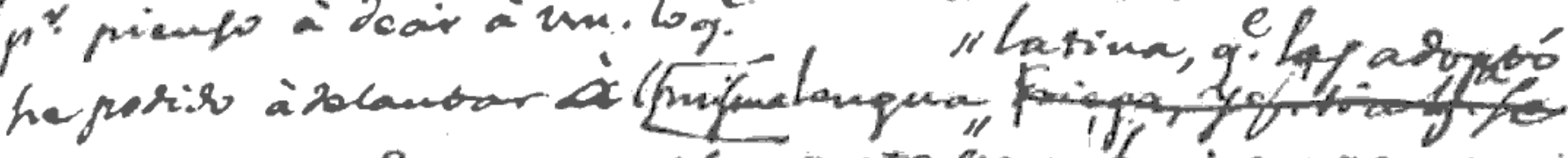

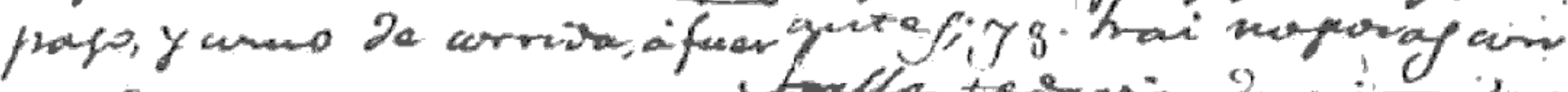

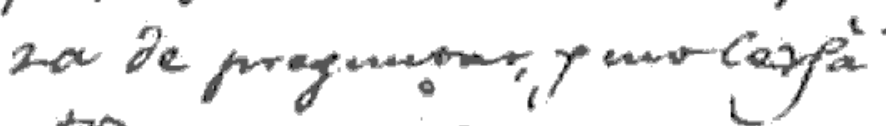

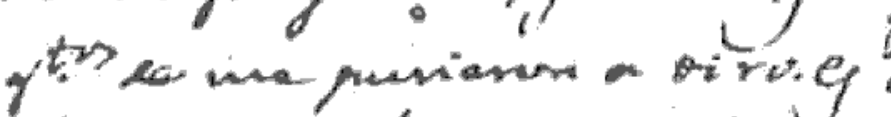

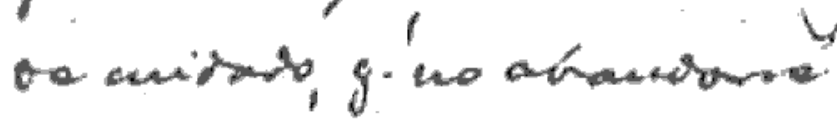

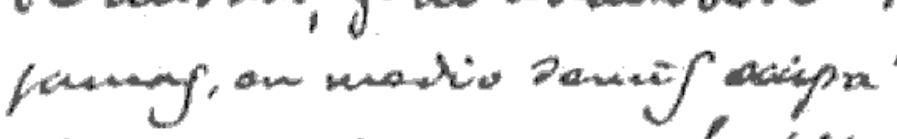

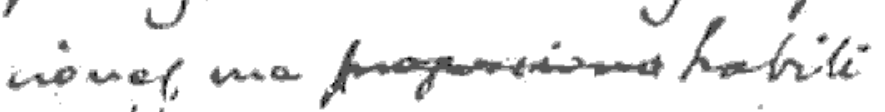
to a s manes pondenes aly

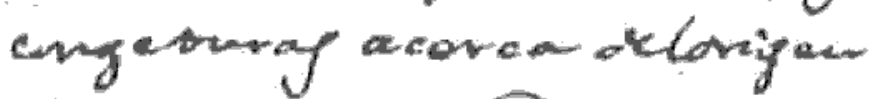
De el tialacero Pffartamely

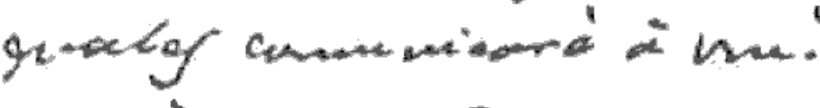

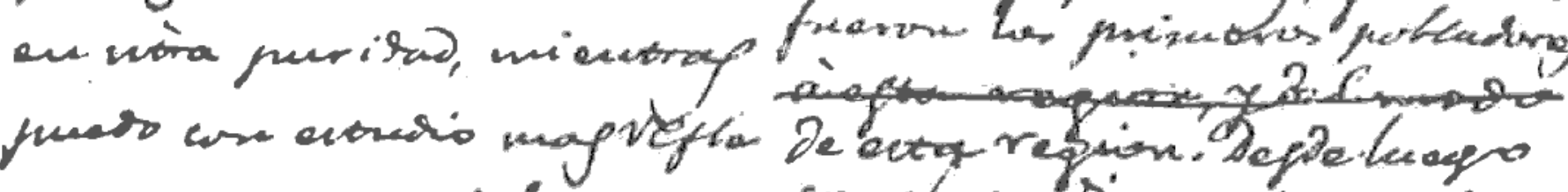

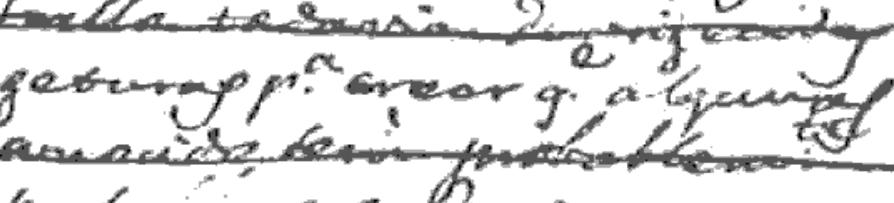

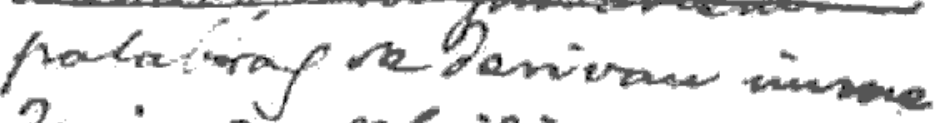

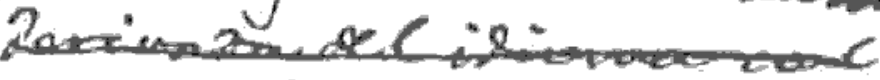

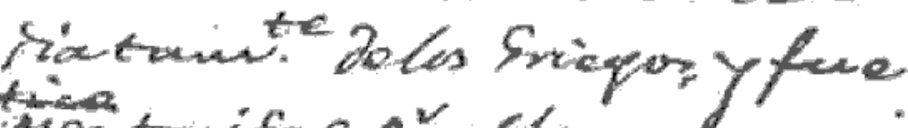

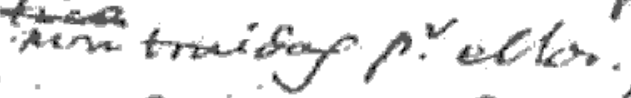

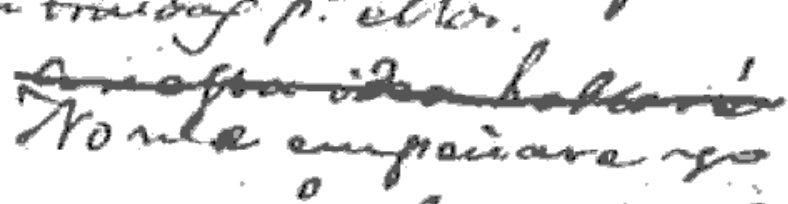

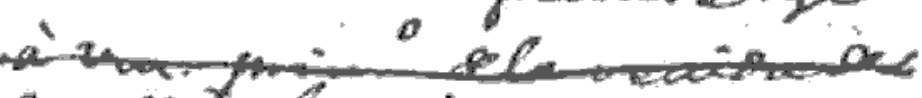

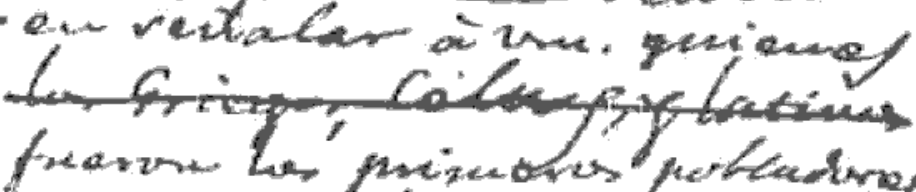

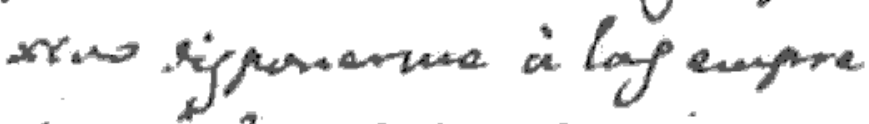
toy 7 . aty un expera in.

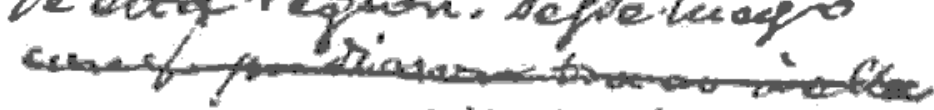

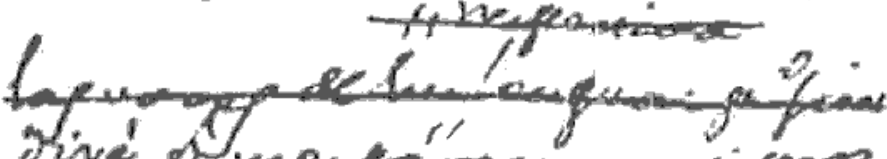
Jive gline mineco munifino

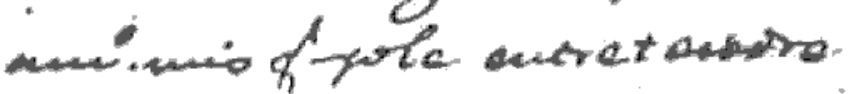
an hos noing ycarsilanomg delas ex molugtry. Alay ango

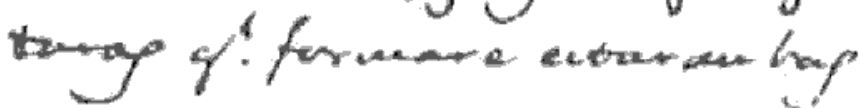

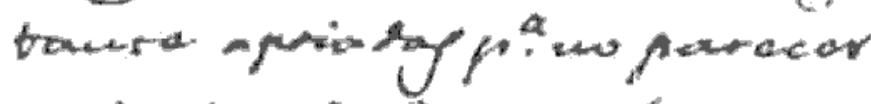

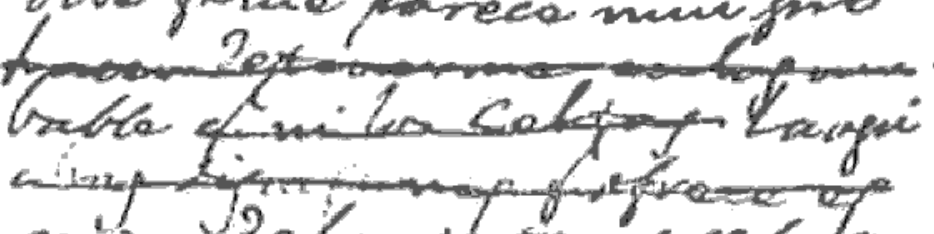

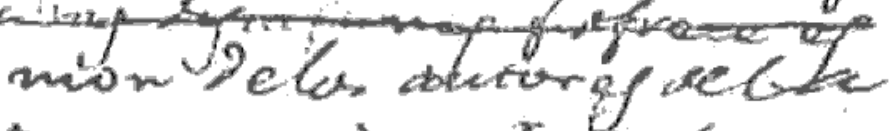

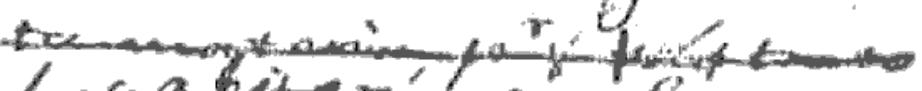

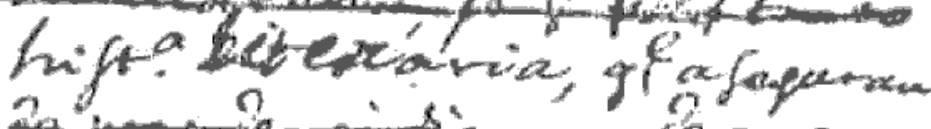

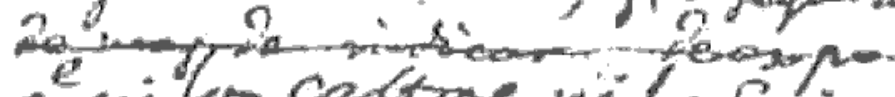

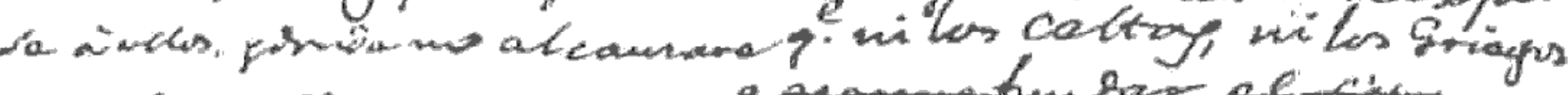

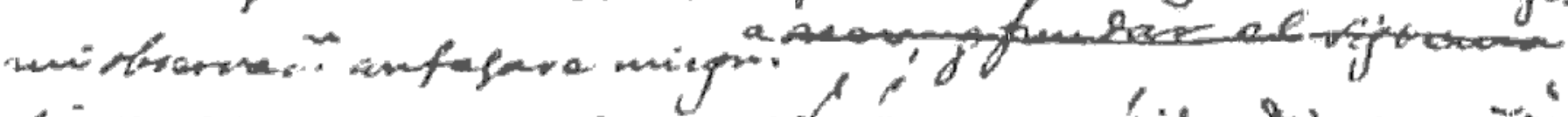

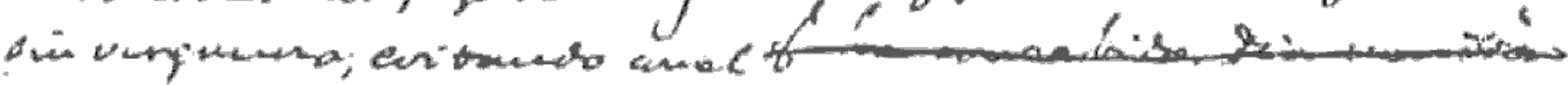




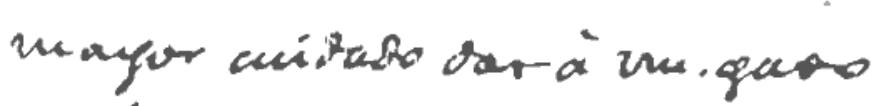
prliabro.

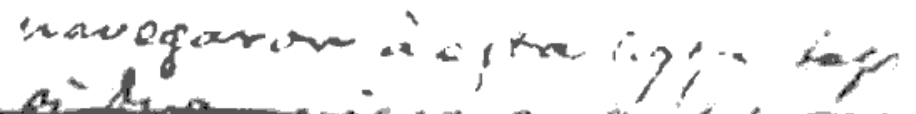

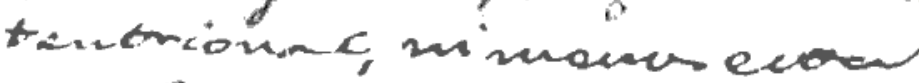

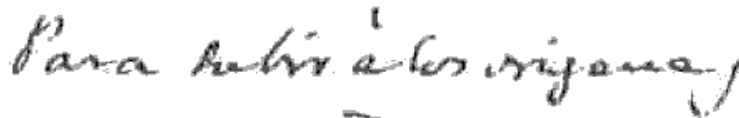

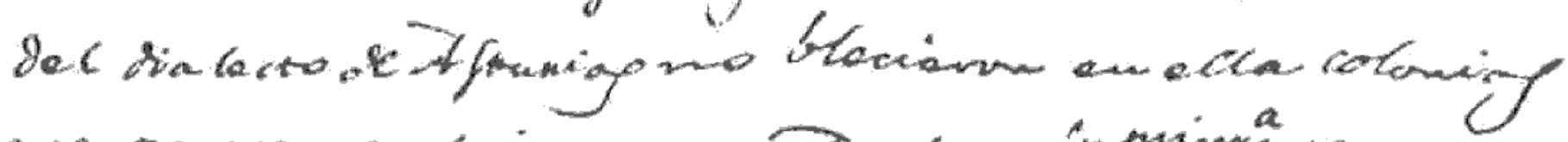

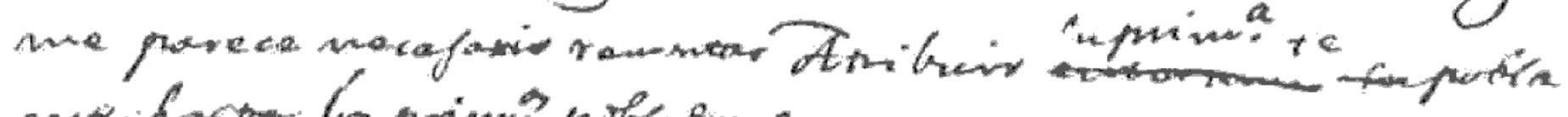

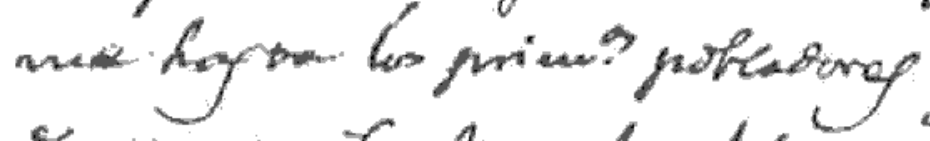

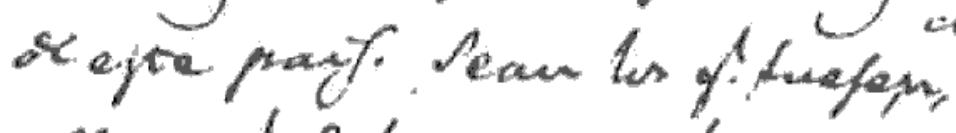

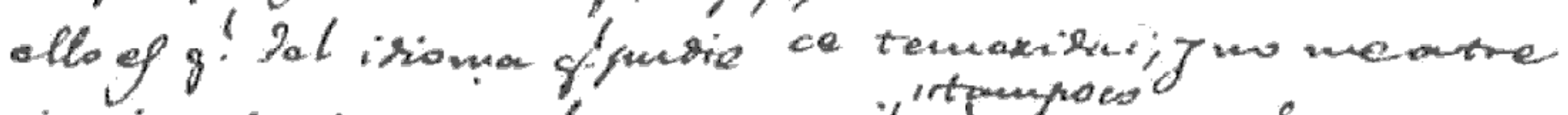

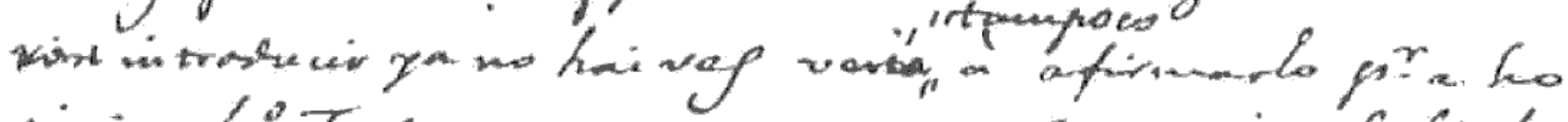

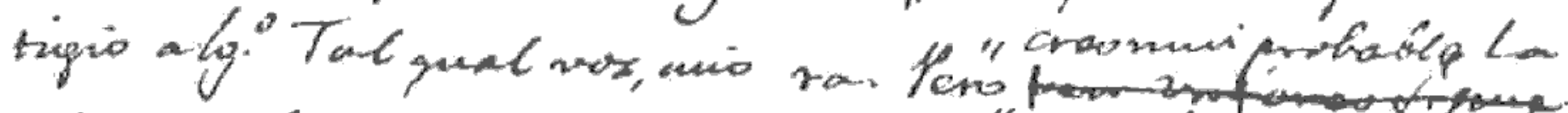

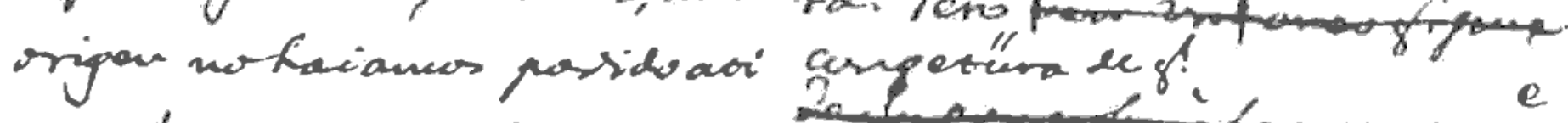

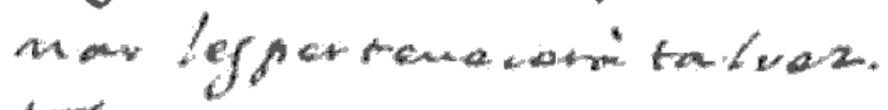

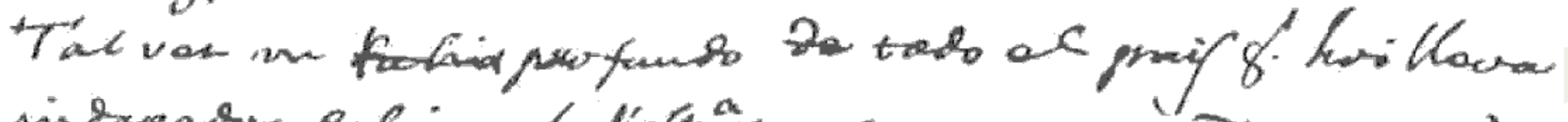

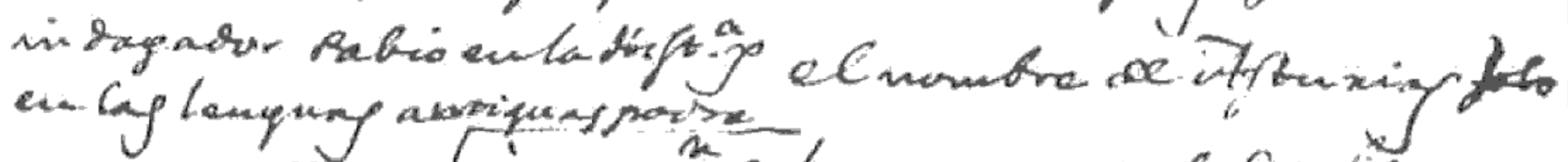

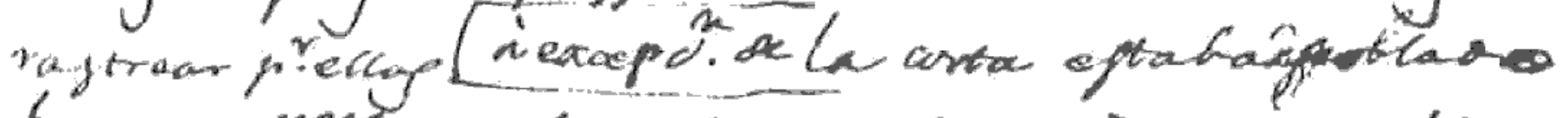

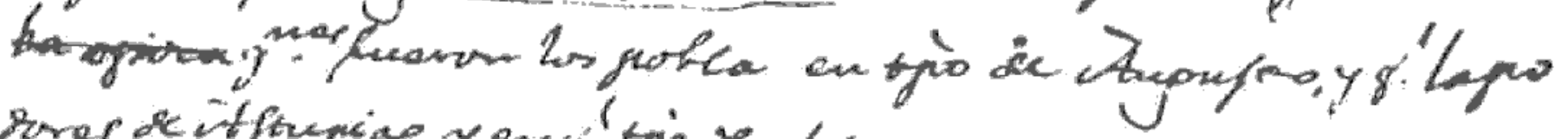

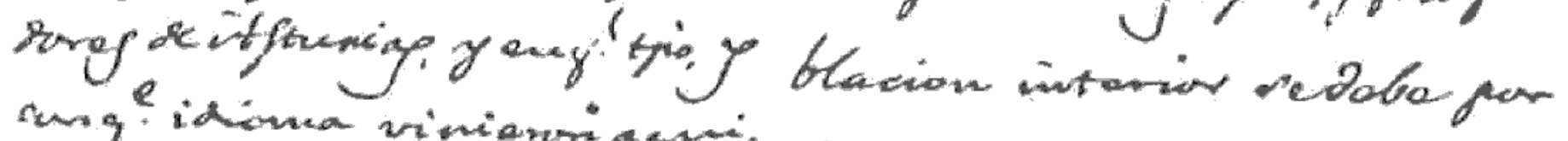
surge idione vinianriagni.

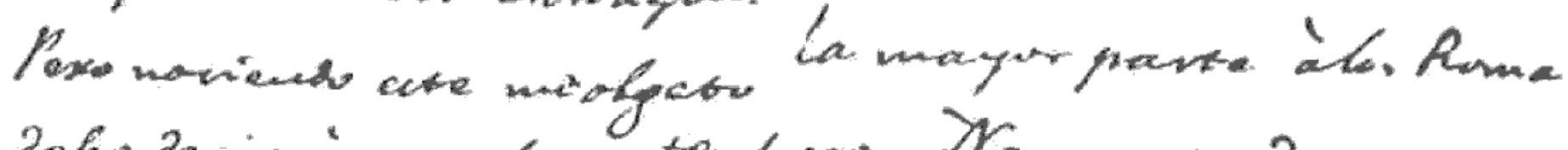

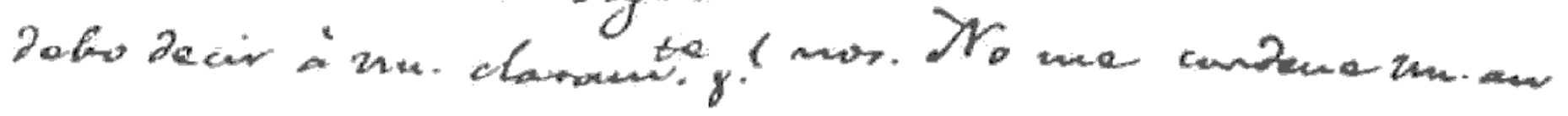
mo cunasto an aftes. tej cetorme.

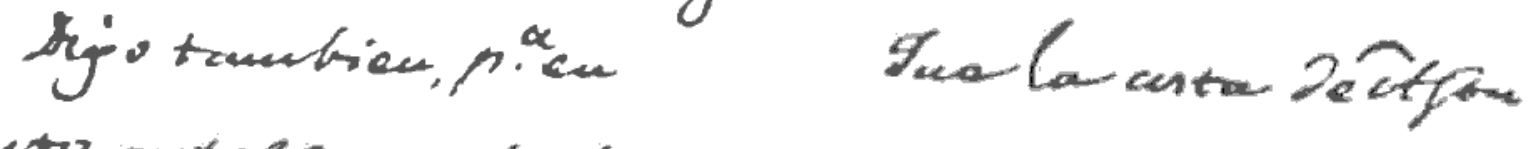

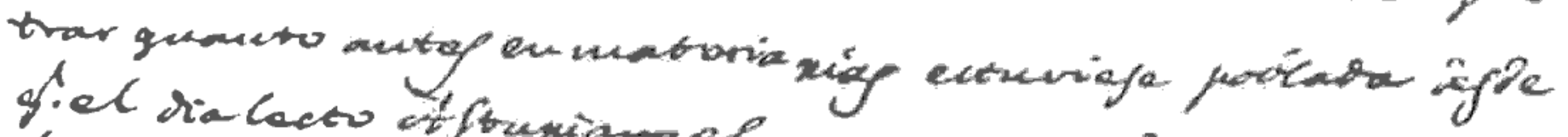

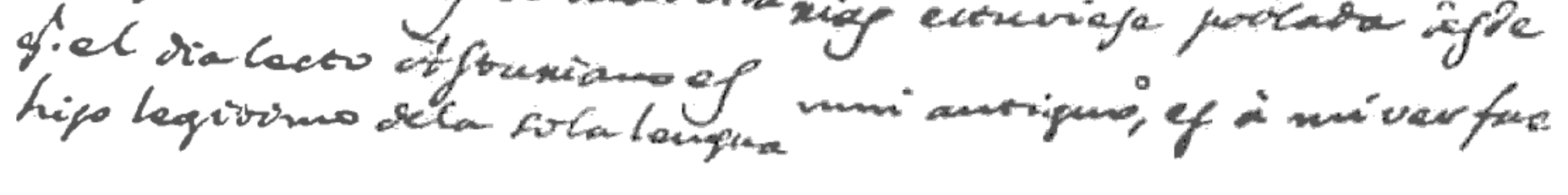




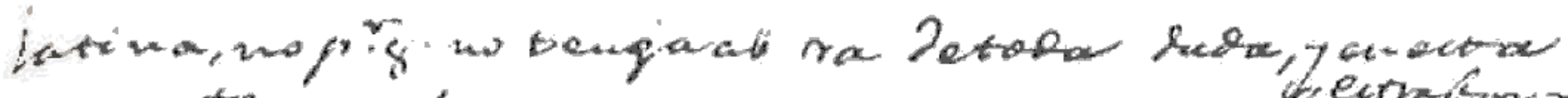

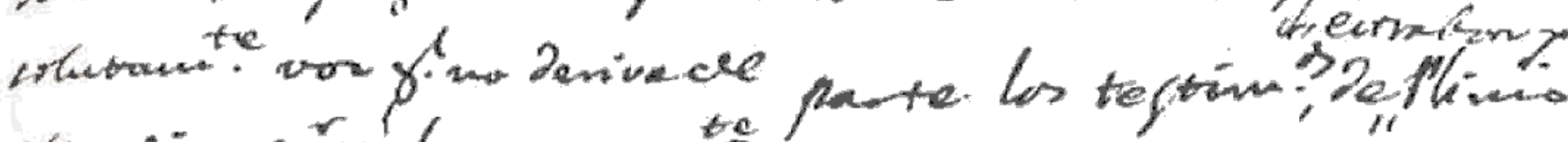

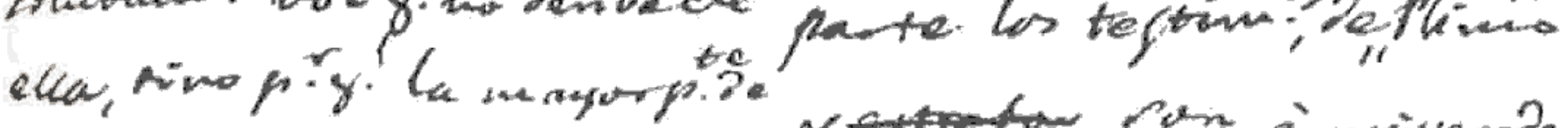

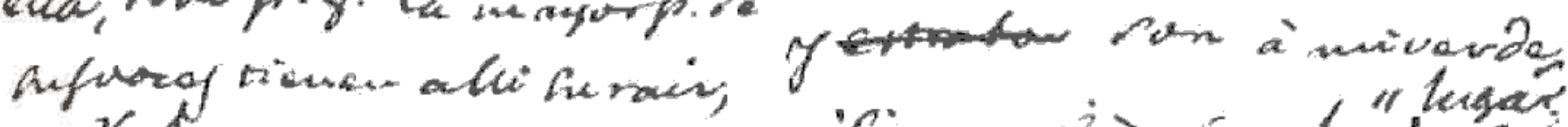

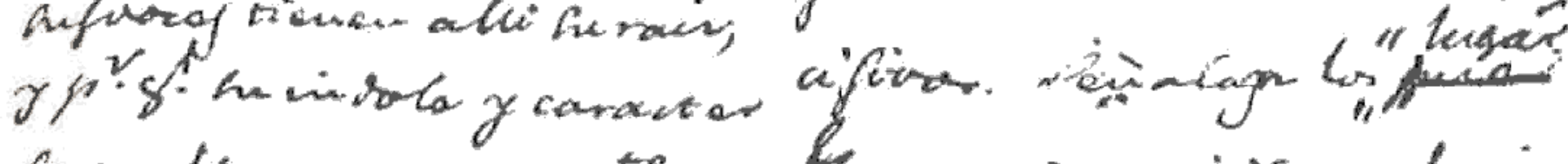

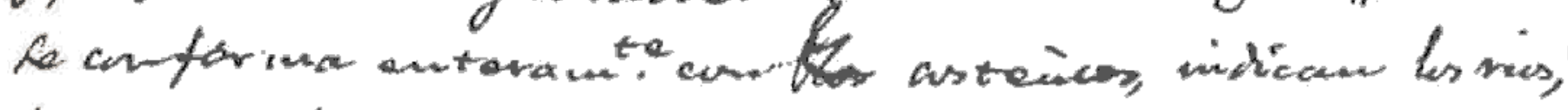
los Rectar languar matrir.

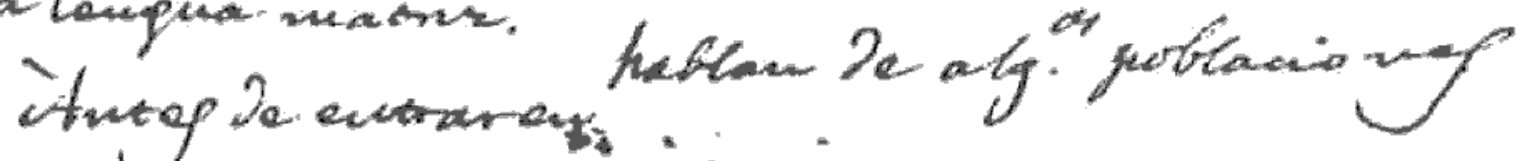
a intercireg

mif angetrong, grasmitioma.

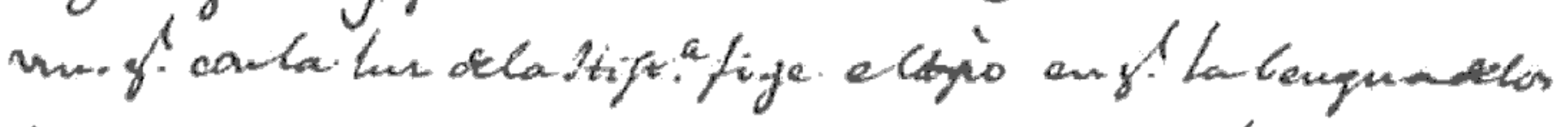

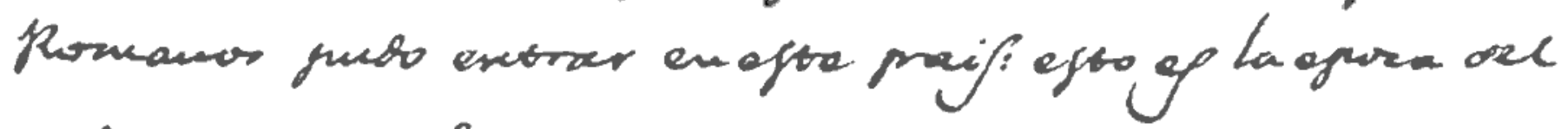
primen origen secte rialecto.

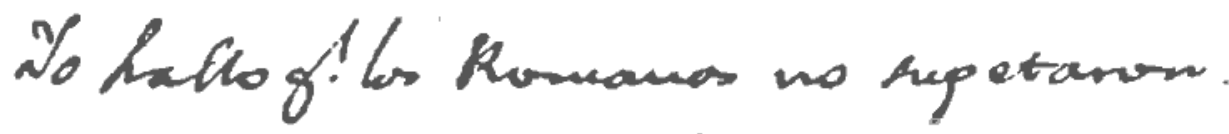

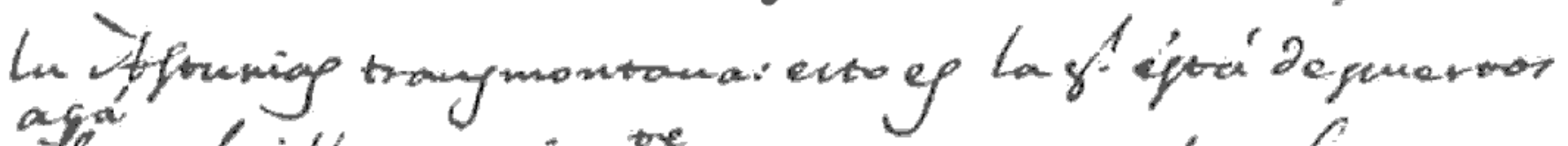

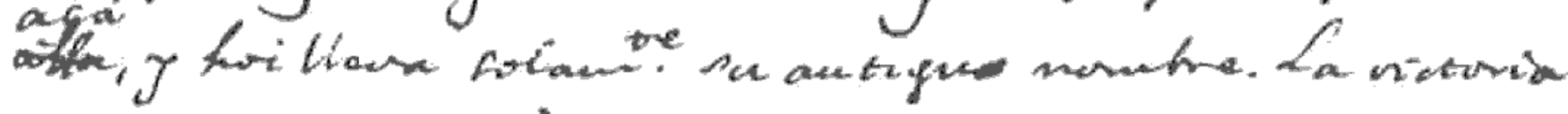

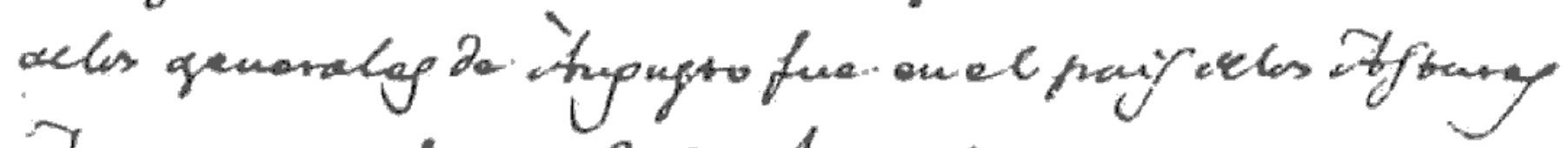

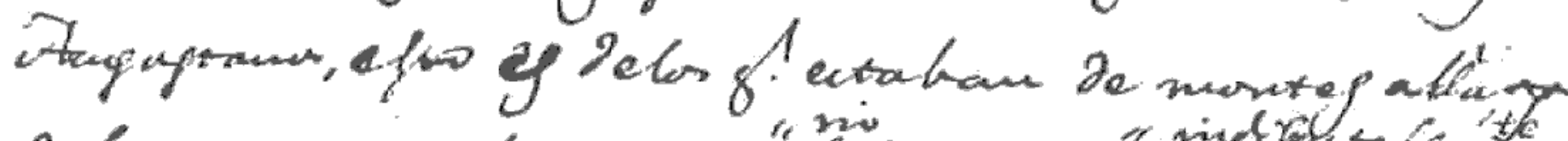

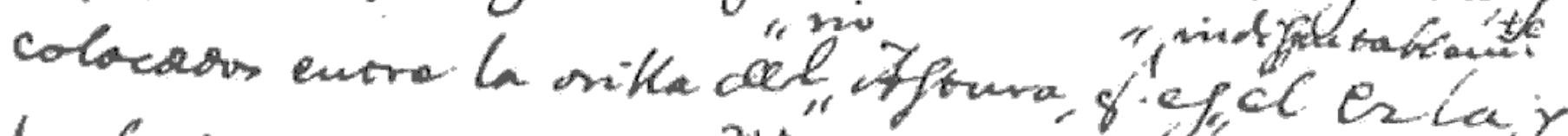
la falba manilional eftros

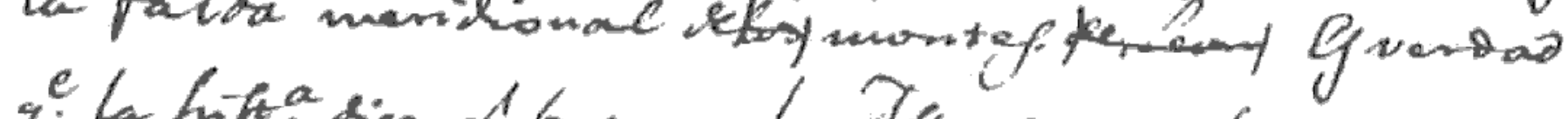

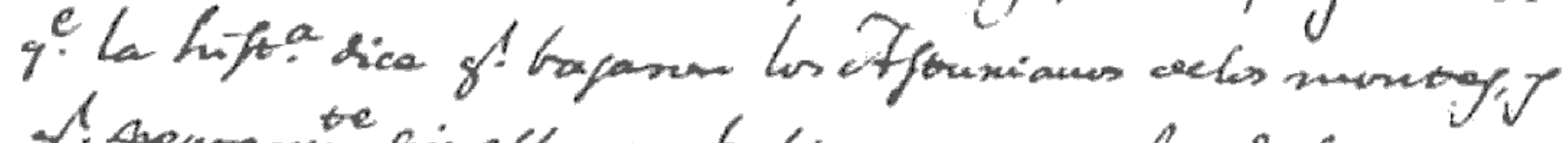

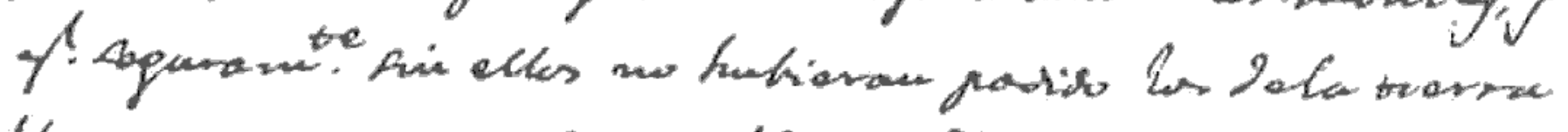

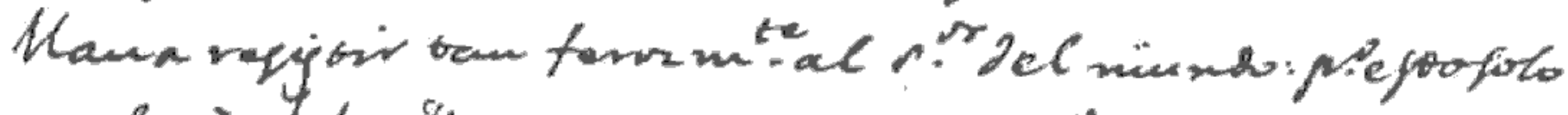

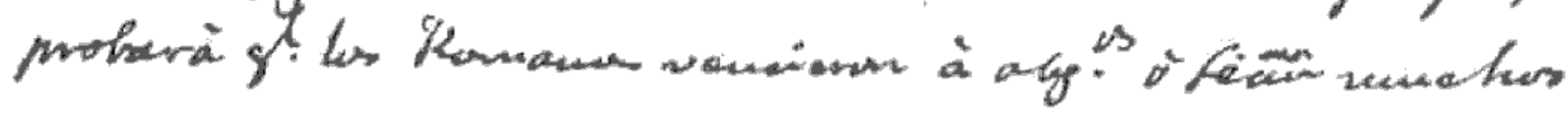




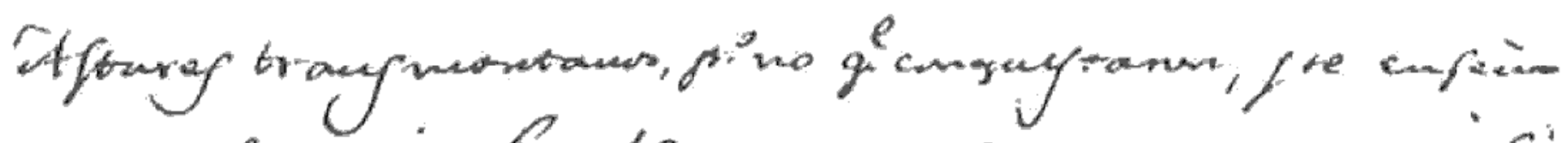

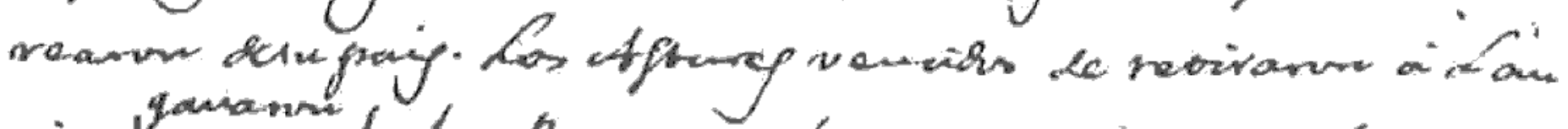

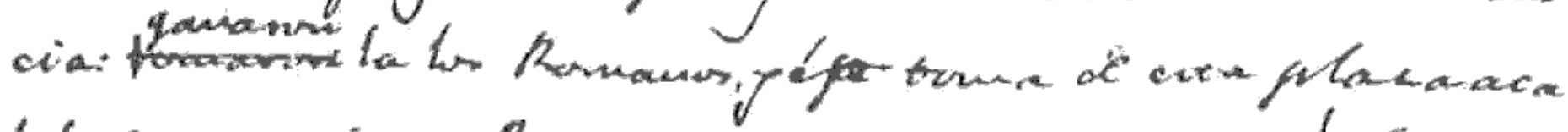

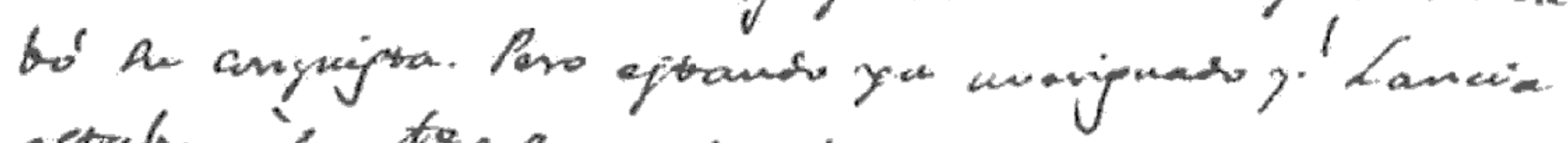

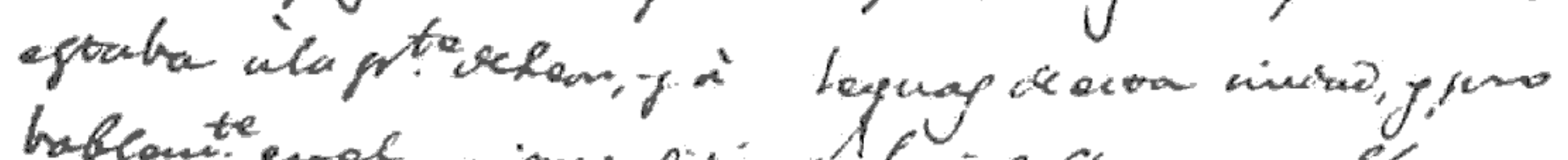

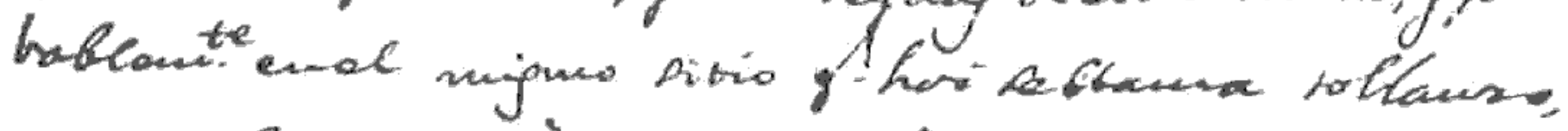

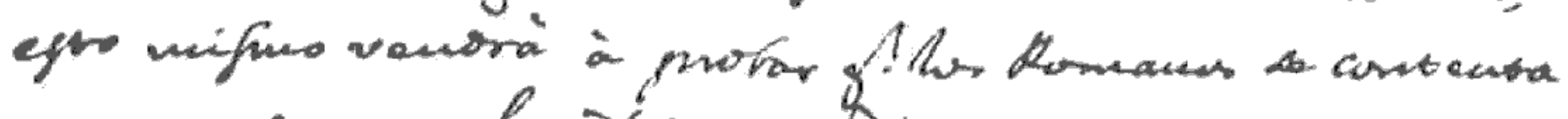

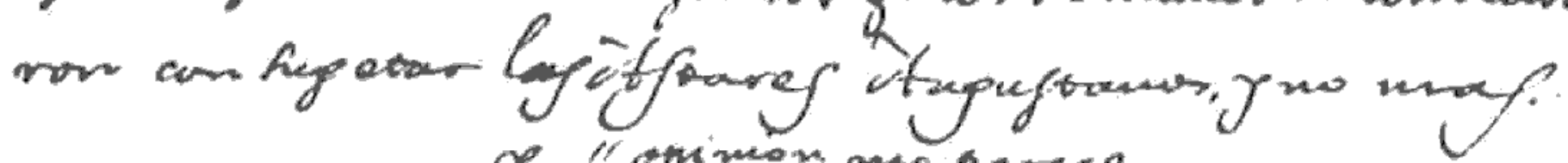

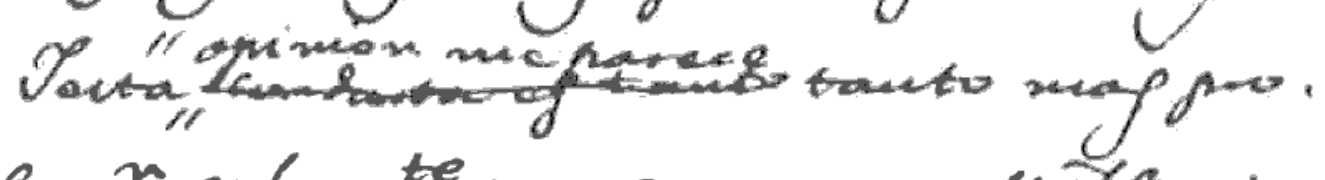

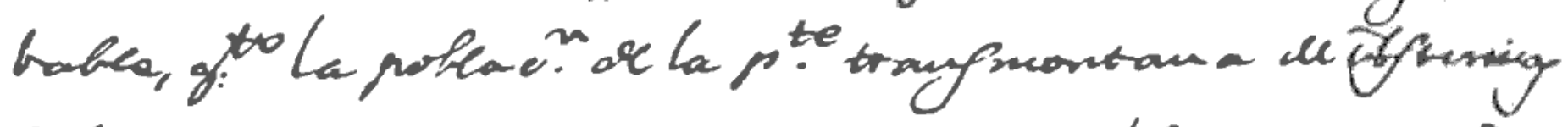

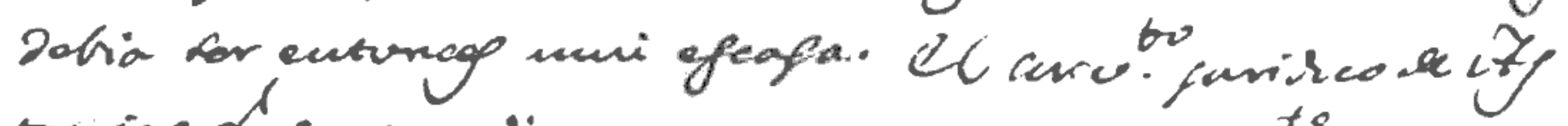

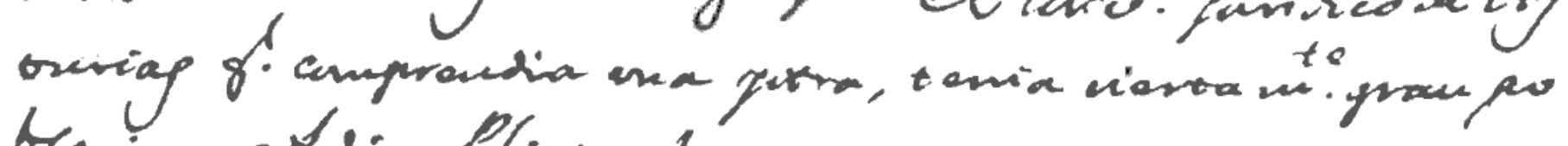
blacion, fotice Plimio git antemia isscicutaly mil

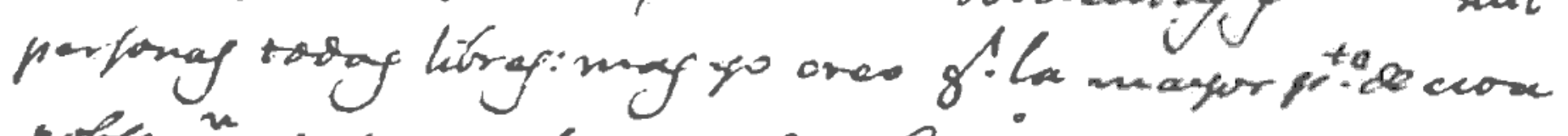

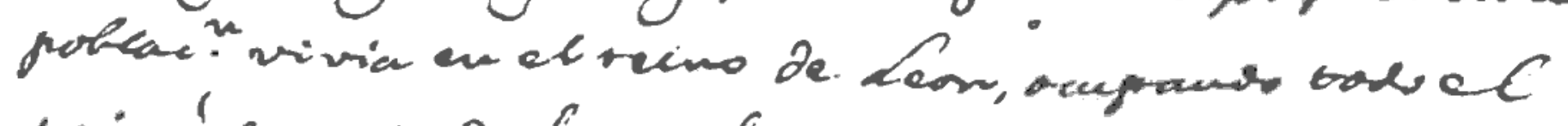

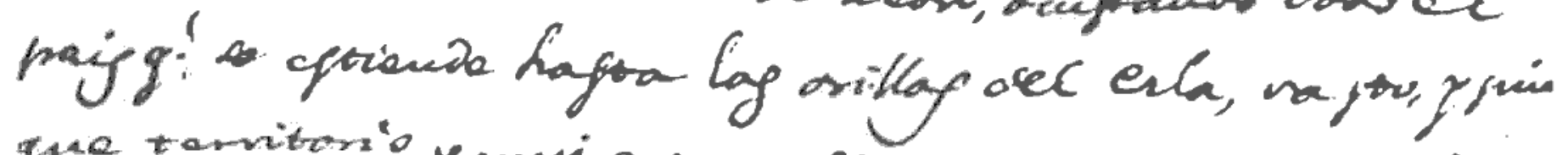

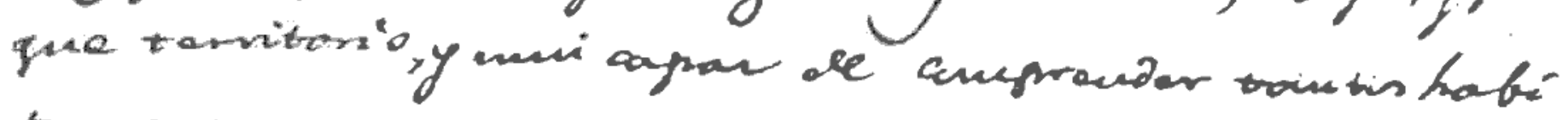
bantiy.

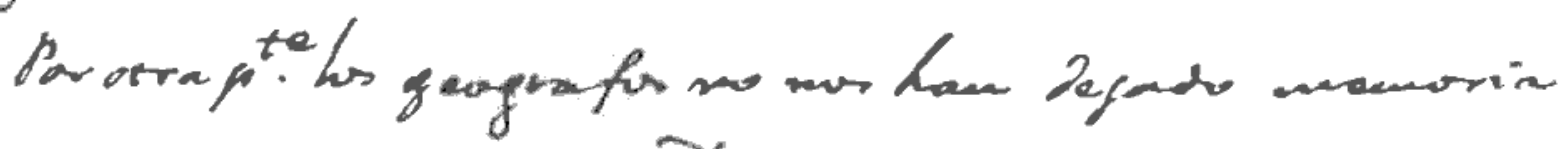

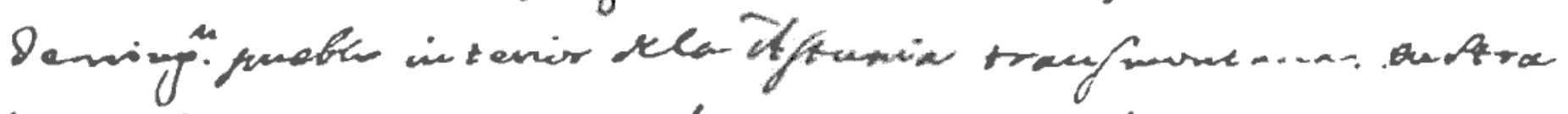

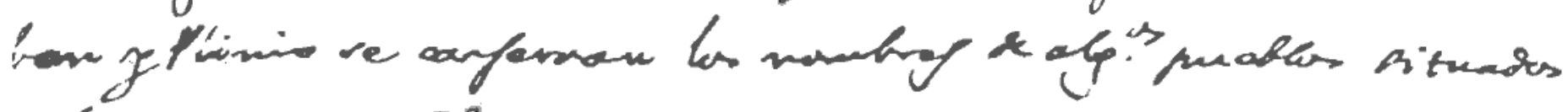

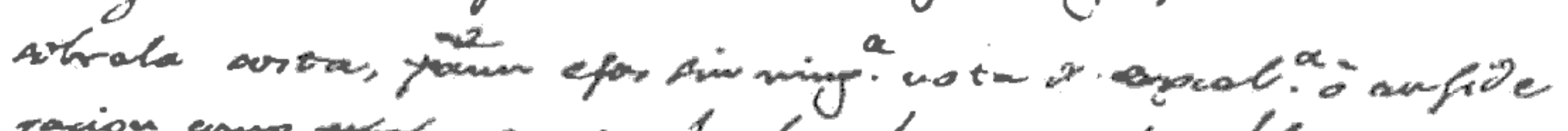

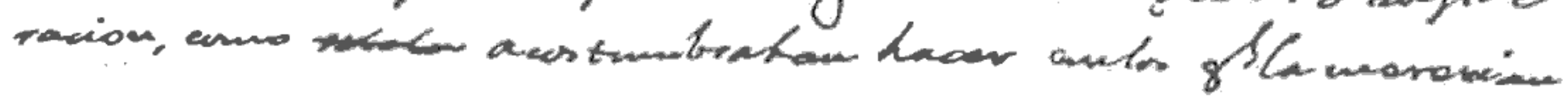




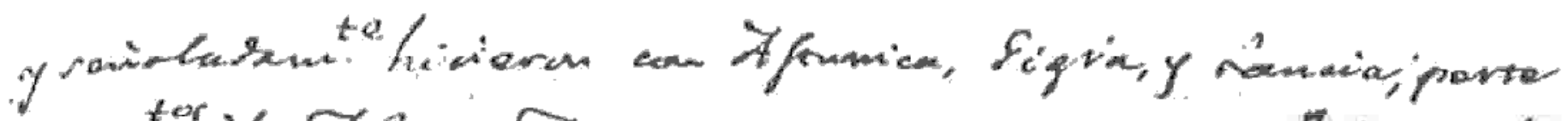

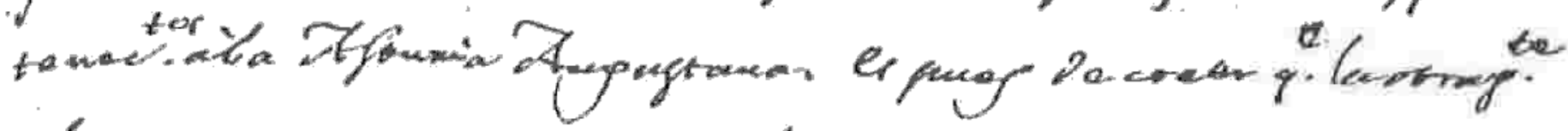

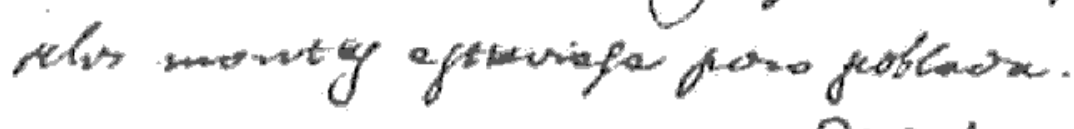

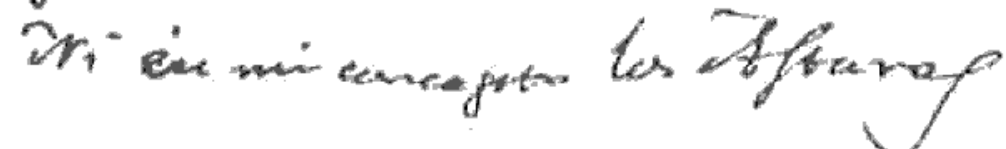

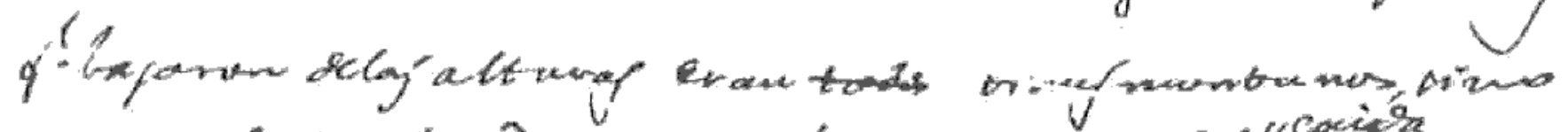

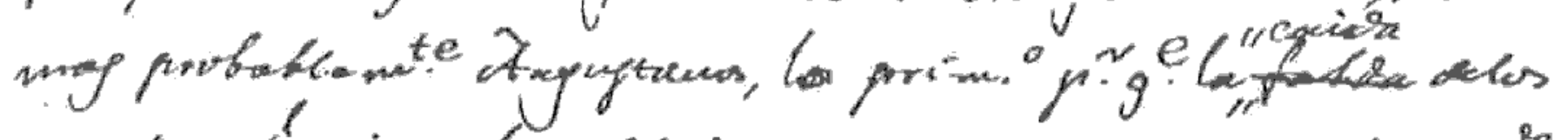

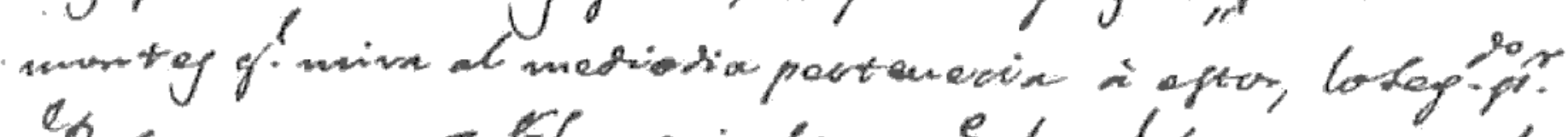

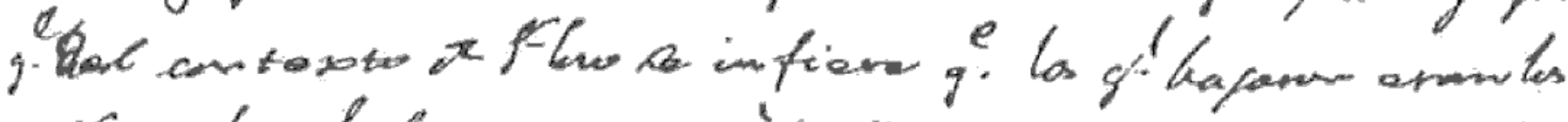

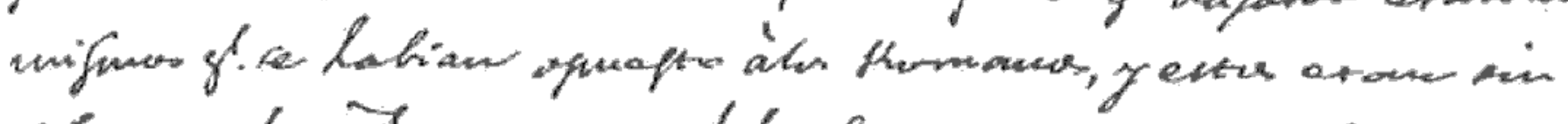

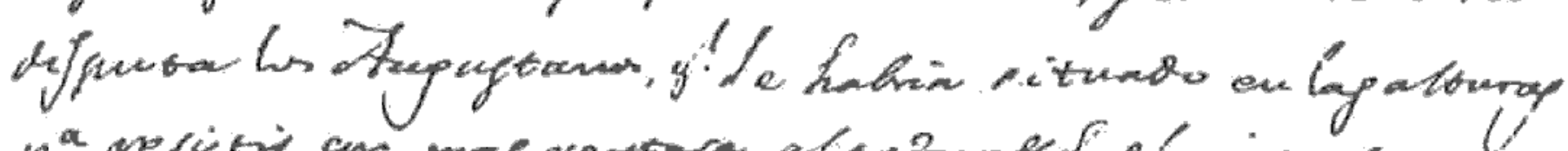

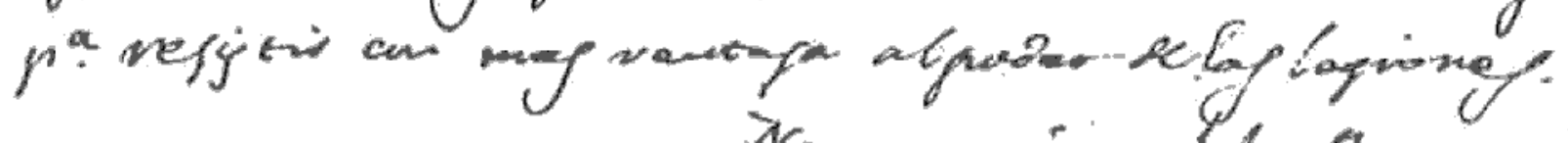

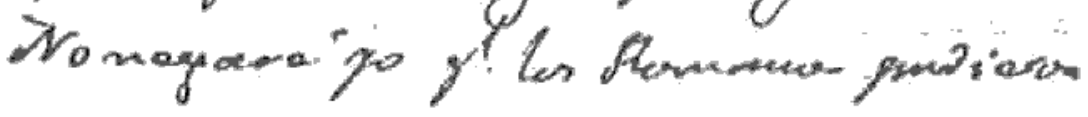

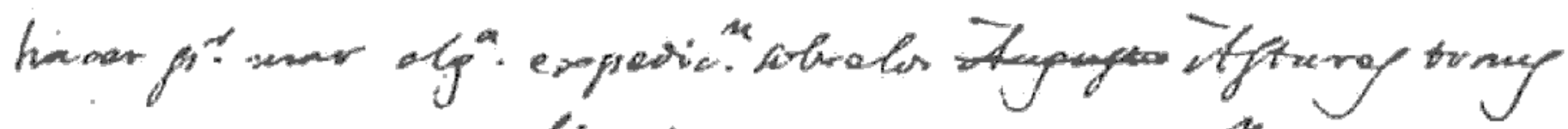

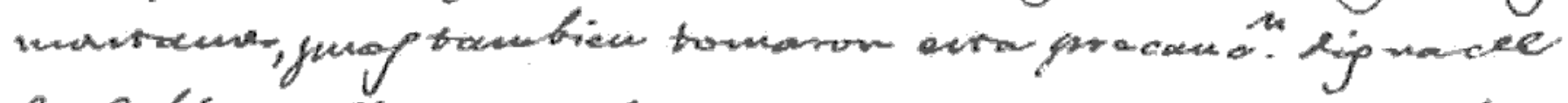

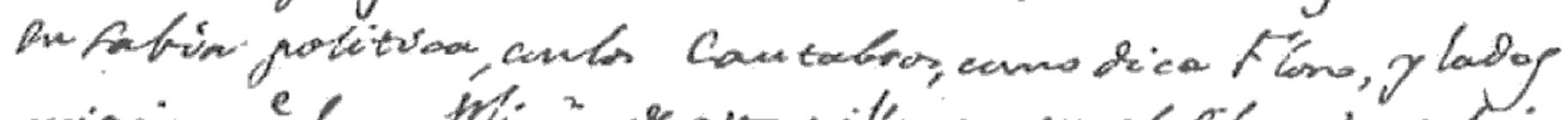

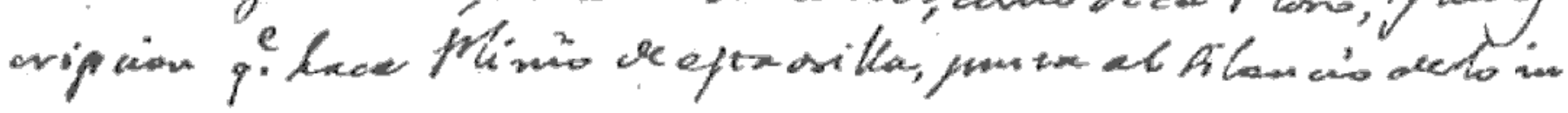

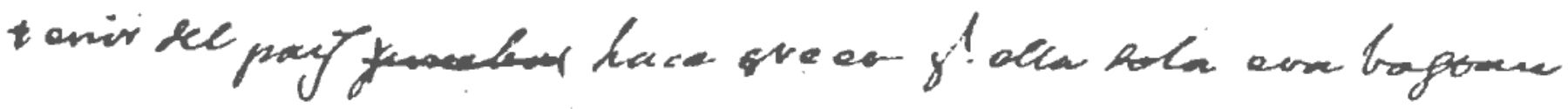

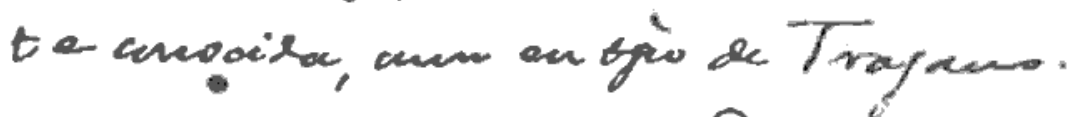

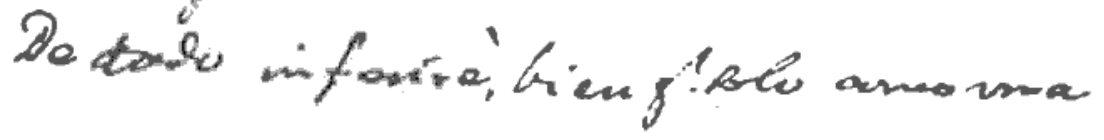

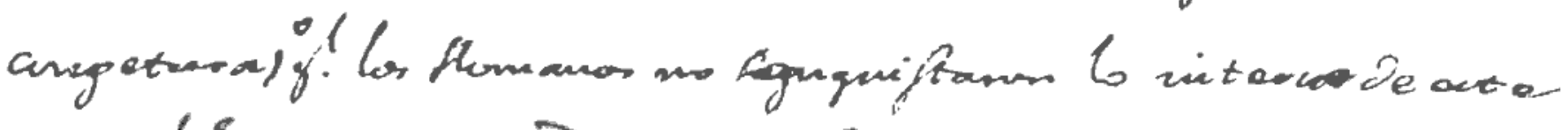

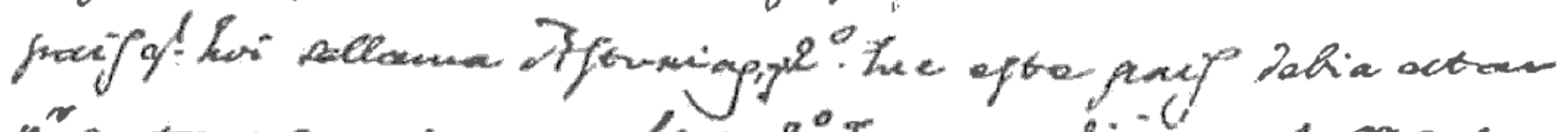

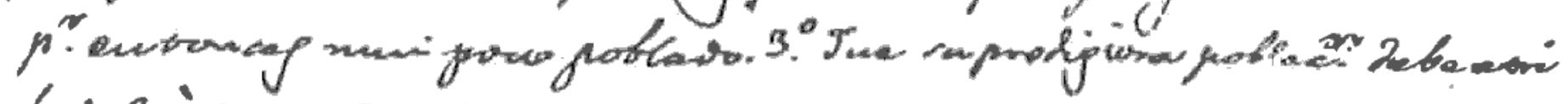
bringa àtor mifunsothemanos.

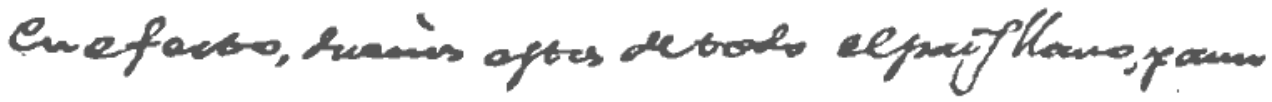




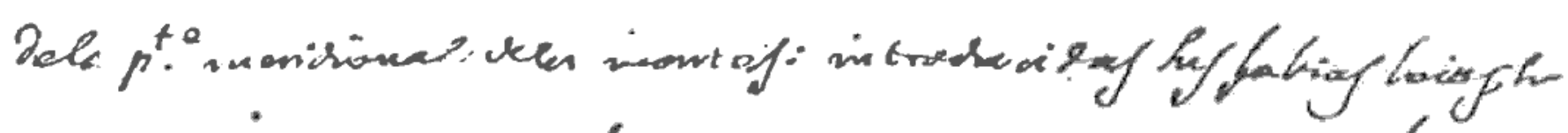

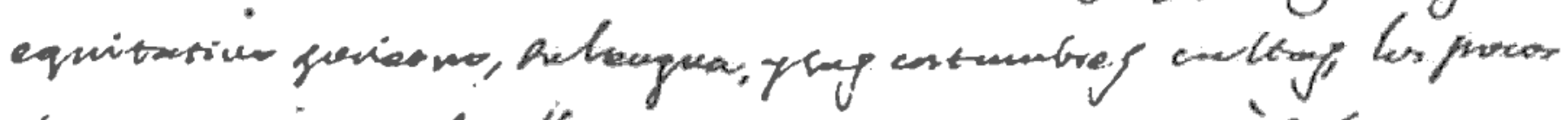

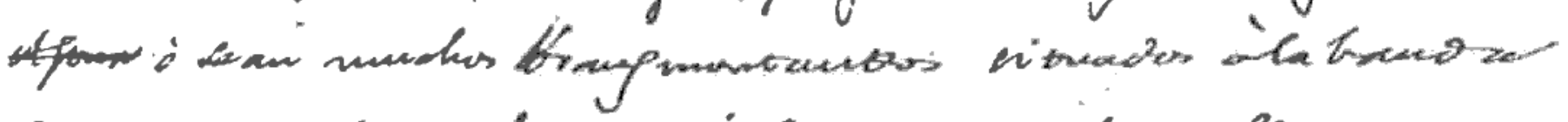

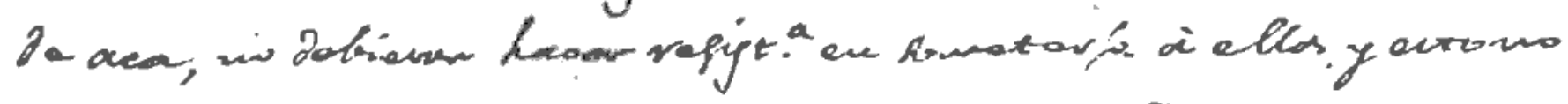

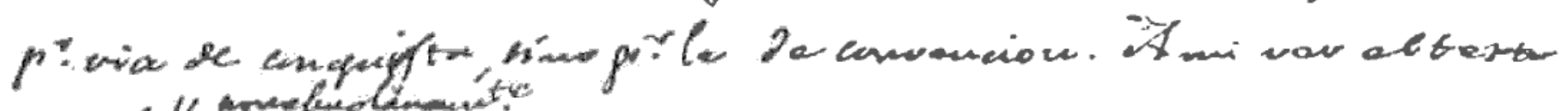

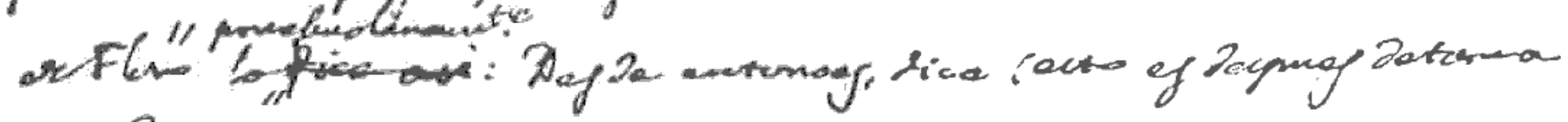
sat haurria....

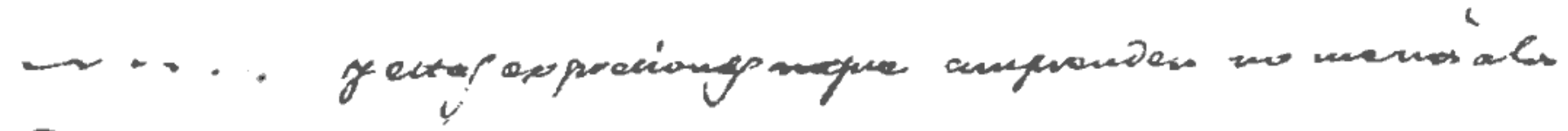

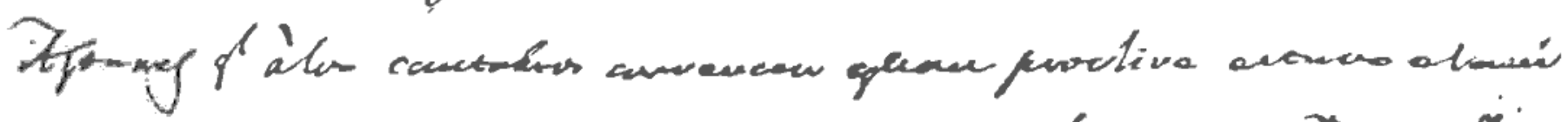

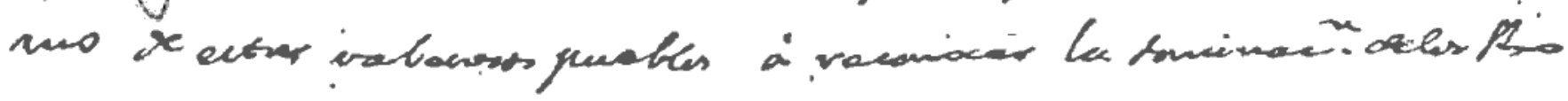
manos. 